\title{
WITCHCRAFT COURT CASES IN THE GRAND DUCHY OF LITHUANIA IN THE SIXTEENTH TO EIGHTEENTH CENTURIES
}

\author{
Gitana Zujienè
}

\begin{abstract}
The article presents an analysis of court procedures against witches in Lithuania. The author explains which courts handled such cases and which legal acts regulated the course of these procedures. The witchcraft court procedure in Lithuania is compared to a procedure discussed in a book by Jakob Sprenger and Heinrich Institor (Kramer) from 1487 called 'Malleus Maleficarum' (Hammer of the Witches). The similarities and differences between these court procedures are revealed.
\end{abstract}

A belief in supernatural powers exists in all religions and cultures, extending to the creatures and people who possess such powers and are able to communicate with them or adopt their skills. Some were trusted and their prophecies were heeded, their power to heal was highly appreciated. Others were avoided at all costs, and even feared. The difference always lay in the source of those powers, whether they arose from good or evil, gods or demons, and what purpose those powers served, to help, or to cause harm. Punishment awaited those who used spells for doing evil deeds since time immemorial. However, only in the second half of the 14th century did that punishment develop into an uncontrollable, blind persecution of people merely suspected of such activities, ending with their merciless elimination. The opinion was formed that spells and curses arose from the Devil's will. Apostasy and acceptance of the Devil's help, or making the proverbial deal with the Devil, was declared the greatest heresy. ${ }^{1}$ At the Fifth Council of the Lateran

${ }^{1}$ The bull of Pope John XXII of 1326 Super illius specula, published by T. Gałuszka, 'Magia jako factum haereticale. Wokól bulli Jana XXII Super illius specula', Przeglad Historyczny, z. 2 (2006), p. 234. The papal bull of Innocent VIII of 1484 Summis desiderantes. Translation into English: http://web.archive.org/ web/20080523174317/http://www.malleusmaleficarum.org/mm00e.html (accessed on 0612 2011). 
in 1514, witchcraft was recognised not just as heresy, but as a secular crime as well. ${ }^{2}$ The fiercest court procedures against witches took place in Germany, Switzerland and France. Other European countries and America were not far behind. The Grand Duchy of Lithuania (GDL) remained on the periphery of these events. The scale of witch-hunts here was much more modest, as was the number of victims. According to the research data, of almost 400 people accused of this crime, only every fifth suspect actually received the death sentence, ${ }^{3}$ and almost $14 \%$ were completely acquitted. We should also note that in Western Europe, the majority of the accused in such court procedures were women. Between the 14th and the mid-17th centuries, the percentage of accused who were women was $85 \%$ in Germany, around $90 \%$ in France, and almost $100 \%$ in Switzerland. ${ }^{4}$ Even in neighbouring Poland, this figure was around $90 \%$. Lithuania comes across somewhat differently in these statistics. Here, women made up only around $60 \%$ of the total number of people accused of witchcraft. A similar situation existed in Estonia (60\%) and Finland (around 50\%). In Russia, men were more frequently accused than women. ${ }^{5}$ In Iceland, meanwhile, as many as $90 \%$ of those prosecuted in court were men. ${ }^{6}$ This was because in certain regions, the image of a witch was created not just by the stereotypes formed by Christianity that spread from the West, but by local traditions, where from the earliest times, spells and magic were a male domain. Thus the question arises, was the concept of a witch in Lithuania different to that in Western Europe? Did it have anything in common with the procedure discussed in Malleus Maleficarum, the book written by Jakob Sprenger and Henrik Institor in 1487, which aspired to become a guideline text

${ }^{2}$ С.Г. Лозинский, Роковая книга, Я. Шпенгер, Г. Инститорис, Молот ведьм (Санкт Петербург, 2005), p. 40.

${ }^{3}$ G. Beresnevičius, T. Čaplinskas, 'Ragana', Lietuvos Didžiosios Kunigaikštijos kultūra. Tyrinéjimai ir vaizdai, eds. V. Ališauskas, L. Jovaiša, M. Paknys, R. Petrauskas, E. Raila (Vilnius, 2001), p. 562.

${ }^{4}$ B.Y Nachman, 'The European Witch Craze of the 14th to 17 th Centuries: A Sociologist's Perspective', American Journal of Sociology, 86/1 (1980), p. 6.

${ }^{5}$ W.F. Ryan, 'The Witchcraft Hysteria in Early Modern Europe: Was Russia an Exception?', The Slavonic and East European Review, 76/1 (1998), p. 73. In Russia, the accusation of witchcraft was often used as a way of tackling one's political opponents.

${ }^{6}$ M. Pilaszek, 'Fiasko europejskiego polowania na czarownice XVI-XVIII w.?', Przeglad Historyczny, t. XCII (2001), z. 4, p. 472. 
for handling such cases in Western states? ${ }^{7}$ We will try to ascertain how that procedure was implemented, what kinds of punishment were handed down, and what the legal regulation was for such cases.

\section{The concept of a witch in the Grand Duchy of Lithuania}

As Gintaras Beresnevičius and Tadas Čaplinskas have noted, the Lithuanian image of a witch is a combination of the images of an archaic goddess and a real woman sorceress. ${ }^{8}$ In the opinion of Marija Gimbutiene, in Baltic mythology, Ragana (the Lithuanian word for 'witch') was the goddess of the night, winter, death and rebirth, while her name was associated with the potential to make prophecies, to see visions and to know. ${ }^{9}$ She controlled the life of humans, and of nature as well. According to Algirdas Julius Greimas, Ragana was a mythical being, in opposition to Aušrine (Dawn), who could see into the future and divert it in one or another direction. ${ }^{10}$

However, in sources from the Grand Duchy of Lithuania, Ragana (Ragaina) was mentioned only in the late 16th century by Jonas Lasickis (pol.: Jan Lasicki, lat.: Johannis Lasitii, Lasicius), as one of the forest goddesses alongside Medeina. ${ }^{11}$ Vytautas Ališauskas drew a parallel in his study between the Greek goddess Artemis and Gorgon, and the Lithuanian Medeina and Ragaina. In his view, if Medeina, like Artemis, protected the forest, hunting and hunters themselves, then Ragaina was her opposite, like Gorgon to Artemis. She represented nature's wrath, chaos, and unforeseeable and uncontrollable danger, which each person could feel when finding themselves in a dense forest. She inspired terror, and led the gullible to their demise. ${ }^{12}$ The author also highlighted her bond

${ }^{7}$ Traditionally, both authors of Malleus Maleficarum used to be identified, but recently the prevailing opinion in historiography is that the author of the book was only H. Institor (H. Kramer) - P. Segl, 'Heinrich Institoris. Persönlichkeit und literarisches Werk', Der Hexenhammer. Entstehung und Umfeld des Malleus maleficarum von 1487, ed. P. Segl (Köln-Wien, 1988), pp. 103-126.

${ }^{8}$ G. Beresnevičius, T. Čaplinskas, Ragana, p. 566.

${ }^{9}$ M. Gimbutienè, Senovés lietuviu dievai ir deivès (Vilnius, 2002), pp. 55-62.

${ }^{10}$ A.J. Greimas, Lietuviu mitologijos studijos (Vilnius, 2005), pp. 152-153.

11 J. Lasickis, 'Apie žemaičių, kitų sarmatų bei netikrų krikščionių dievus', Baltu mitologijos ir ritualo tyrimai, t. 6 (Vilnius, 2012), p. 111. (latin - De diis Samagitanim caeterorumque Sarmatarum et falsorum Christianorum, written ca. 1582 and published in 1615)

${ }^{12}$ V. Ališauskas, 'Jono Lasickio pasakojimas apie žemaičių dievus: tekstas ir kontekstai’, ibid., p. 72 . 
with the world of the dead. Whereas the cult of Medeina gradually disappeared, the image of the witch, in his view, remained in folk belief, and was further developed. According to the author, a witch lived beyond the boundaries of cultural space, and her behaviour demolished the established world order.

Norbertas Vèlius made the distinction between two phenomena: sorcery/witchcraft, which was done in order to cause someone harm, and sharing prophecies, in order to help people. He believes that both orientations emerged in early human society. As agriculture and the domestication of animals developed, these images of the sorcerer/ witch and the prophet/priest were supplemented with the respective traits of wanting to harm or help animals and plants. ${ }^{13}$ Christianity adapted and enhanced the image of the witch with new aspects.

The position of Vytautas Kavolis does not fit well into this context. In his view, the she-witch of archaic Lithuanian culture did not have any negative connotations. She was depicted as an elderly woman, not necessarily belonging to the community, but helping it with her spells and good advice. ${ }^{14}$ Other authors have also acknowledged the existence of witches and sorcerers doing good deeds alongside evil-doers. ${ }^{15}$ Yet Kavolis reached this conclusion solely on the basis of one folk story, Eglè, žalčiu karalienè (Eglè, Queen of the Grass Snakes).

After the conversion of Lithuania to Christianity (1387), elements of the pagan way of seeing the world remained present in people's consciousness for a long time. Even Martynas Mažvydas' Catechism (1547) mentioned village sorceresses that people would go to for help and ancient (pagan?) rituals. ${ }^{16}$ Sources highlight the fact that people appealed to and worshipped pagan gods, demons in the eyes of Christians, and instead frequented sorcerers and prophets rather than the Church as late as the 17th and 18th centuries. The Church did not view this as heresy, but superstition, the result of people's lack of education. Their response was not to exact punishment, but to spread the word of God and Christian truths, and to establish local (folk) missions. ${ }^{17}$ For example, in Jonas Bretkūnas' Postille, published

${ }^{13}$ N. Vèlius, Mitinès lietuviu sakmiu bütybès: laimès, laumès, aitvarai, kaukai, raganos, burtininkai, vilktakiai (Vilnius, 1977), pp. 246-247.

${ }^{14}$ V. Kavolis, Moterys ir vyrai lietuviu kultūroje (Vilnius, 1992), pp. 33-34.

${ }^{15}$ N. Vèlius, Mitinès lietuviu sakmiu bütybès, pp. 233, 242.

${ }^{16}$ V. Kavolis, Moterys ir vyrai, p. 37.

${ }^{17}$ Vilniaus kolegijos jèzuitų metinès ataskaitos, 1585-1618, Baltu religijos ir mitologijos šaltiniai, sud. N. Vèlius, t. 2 (Vilnius, 2001), (hereafter - BRMŠ2) 
in 1591, he discourages people from celebrating St John's night like witches, although witches were not used to scare or threaten. ${ }^{18}$

Members of the secular world were stricter where witchcraft was concerned. From the mid-16th century, powiat inventories reveal instructions to local officials 'to ensure that there are no sorcerers or witches, and that all believe in the one God, our Lord'. ${ }^{19}$ The provisions of Eustachijus Valavičius of 1583 to his Naujamiestis subjects mention punishment, while sorcerers and witches are lumped together with thieves, drunks, robbers and adulterers: 'sorcerers, witches, thieves, drunks, robbers, adulterers and those who live together in sin but have not fulfilled the sacrament of matrimony, I order that they and none like them shall be found among my subjects: such people must be strictly punished, and driven from my city and powiat. ${ }^{20}$ This information suggests that in those times, witchcraft was considered a sin and a crime, but not heresy.

However, Western Europe's influence as far as witches were concerned started to be felt in Lithuania as well. In 1570, in Brest-Litovsk, the former Radvila printing house, which was then owned by Cyprianus Basilicus (Cyprian Bazylik), published a book by an anonymous author called Postepek prawa czartowskiego przeciw narodowi ludzkiemu, which elucidated on Lucifer's plan to bring humanity under his control. Several chapters at the end of the book are dedicated to a discussion of witches specifically. Based on the teachings of St. Augustine, the author wrote how witches prayed and made offerings to the Devil, and how they did harm to people with the Devil's help. ${ }^{21} \mathrm{He}$ explained how the Holy Bible banned witchcraft, which would lead to losing one's soul, while according to secular law, perpetrators would be punished by death and be driven from this world. Some examples of the torture of witches in Western Europe were also given. ${ }^{22}$ However, unlike West European

pp. 626-633; 'Nesvyžiaus kolegijos jėzuitų metinès ataskaitos 1606, 1607, 1608', Baltu religijos ir mitologijos reliktai Lietuvos Didžiojoje Kunigaikštystèje (XIVXVIII a.), ed. V. Ališauskas (Vilnius, 2015), pp. 135-136, 339, 341.

${ }^{18} \mathrm{~J}$. Bretkūnas, 'Postilla tatai esti trumpas ir paprastas ischguldimas Euangeliu 1591 ', BRMŠ2, p. 319.

${ }^{19}$ Karšuvos valsčiaus inventorius, 1562, ibid., p. 424.

20 'Eustachijaus Valavičiaus nuostatai Naujamiesčio valdiniams, kaip išlaikyti tikèjimą ir dorovę, 1583 rugpjūčio 4', ibid., p. 615.

${ }^{21}$ A later edition of this book was used, Postepek prawa czartowskiego przeciw narodowi ludzkiemu, wyd. A. Benis (Kraków, 1892), s. 114.

${ }^{22}$ Ibid., pp. 116, 118. 
publications, there was no urging to persecute or kill witches here. The moral of the book was for all good Christians not to believe in spells and curses, not to take part in melting wax to foresee the future, to avoid incantations, and not to draw conclusions from one's dreams, as that went against one's conscience and left one open to the Devil's influence. ${ }^{23}$

Piotr Skarga's Źywoty Świętych (Lives of the Saints) appeared in Vilnius in 1579 , where a great deal of attention was given to holy people's struggles against the Devil, against the possessed, witches and spells. ${ }^{24}$ The idea of believing in some people's ability to communicate with the Devil and seek his help in order to harm others found its way into Lithuania. The clergy, especially the preaching orders, facilitated the spread of images of the Devil, and witches, his collaborators, among the broader masses. We cannot deny that the collaboration between witches and the Devil, as two mythical beings, was already known of in pagan Lithuania. However, it now took on a completely different meaning. The image in people's consciousness of a witch-sorceress was gradually replaced by the image of her as the Devil's helper.

A similar evolution of spells, from being protective to being dangerous in society, can be noticed in Lithuanian legal acts from the 15th and 16th centuries as well. The use of spells was mentioned for the first time in Casimir's Code of 1468. It warned of the possibility of using spells (herbs/potions) during torture in order to avoid pain. ${ }^{25}$ The First Statute of Lithuania of 1529 specifically mentioned spells rather than herbs. ${ }^{26}$ The Second Statute of Lithuania of 1566 identified where such spells could be found, in the mouth, hair and armpits of the accused, ${ }^{27}$ in the same places where spells were searched for during witches' trials in Western Europe. There was no direct punishment for the use of spells as such. However,

${ }^{23}$ Ibid., p. 120.

${ }^{24}$ P. Skarga, Żywoty Świętych (Wilno, 1579).

${ }^{25}$ Kazimiero teisynas, compiled by J. Jurginis (Vilnius, 1967), p. 18, Article XVIII.

${ }^{26}$ С. Лазутка, И. Валиконите, Э. Гудавичюс, Первый Литовский Статут (1529 2.) (Вилнюс, 2004), XIII. 14. English translation of the First Statute of Lithuania: The Statute of Lithuania, 1529 - Lietuvos Statutas, 1529 - Statuta Lituaniae, 1529, translated by K. von Loewe, E. Gudavičius (Vilnius, 2002).

27 T.I. Доўнар, Статут Вялікага княства Літоўскага 1566 года, (Мінск, 2003), XIV. 15. 
a person suspected of using spells during torture was immediately considered guilty. ${ }^{28}$ The Third Statute of Lithuania of 1588 repeated the same provisions regarding spells, and compared witchcraft to a criminal act. ${ }^{29}$

\section{I.2. Historiography}

The history of witches became a topic of interest in Lithuania in the 19th century. Dionizas Poška, in his work on ancient Lithuanian religious rituals, wrote about male and female witches and their traditional meeting place on Šatrija Hill. ${ }^{30}$ Liudvikas Adomas Jucevičius, in his book Žemaičiu žemès prisiminimai (Memories from the Land of the Samogitians) of 1842, publicised several cases of witchcraft. ${ }^{31} \mathrm{He}$ recounted tales about Šatrija Hill and witch gatherings, as if they were folk stories. Mitrofan Dovnar-Zapolsky used excerpts from the latter source when writing about witchcraft in the northwest of the Russian Empire in the 17th and 18th centuries. ${ }^{32}$ Motiejus Valančius was the first, in his Žemaičiu vyskupysteje (In the Samogitian Diocese) in 1848, to give a brief history of the persecution of witches in Lithuania, highlighting the main moments. He also publicised several court cases on witchcraft. ${ }^{33}$ Later, numerous authors repeated the information presented by Valančius when writing about witchcraft trial procedures. ${ }^{34}$ In 1896, Ivan Sprogis published one court case on witchcraft from 1615 as a separate publication. ${ }^{35}$ In the second half of the 19 th century, several more witchcraft cases were published in the journal

${ }^{28}$ In the article, it is said that during torture, an accused who used spells to avoid feeling pain, appearing to fall asleep (probably having lost consciousness), had to pay the plaintiff as much as they requested.

${ }^{29}$ Статут Вялікага Княства Літоўскага 1588, ред. І. П. Шамякін (Мінск, 1989), XIV. 18; IV. 30.

${ }^{30}$ D. Poška, Raštai (Vilnius, 1959), p. 375.

${ }^{31}$ L. Jucevičius, Raštai (Vilnius, 1959), pp. 177-178, 406-413, 476-498.

32 M.В. Довнар Запольский, Чародейство в Северо-Западном крае в XVIIXVIII вв., Исследование и статьи, т. 1 (Киев, 1909), pp. 214-231.

${ }^{33}$ M. Valančius, Raštai, t. 2 (Vilnius, 1972), pp. 342-352.

34 Памятная книжка Ковенской губернии на 1900 год (Ковна, 1899), c. 3146-3156; P. Šinkūnas, 'Lietuviški žavètojai ir raganos', Mokykla ir gyvenimas, no. 6 (1930), pp. 293-301; K. Kiela, 'Raganų deginimas Lietuvoje', Diena (1935 liepos 7.); Lietuvos žinios (1935 rugpjūčio 25 d.).

${ }^{35}$ И. Спрогис, Народный суд литвинов над колдунами (Витебск, 1896). 
of the Vilnius Archaeographic Commission. ${ }^{36}$ In 1922, Kazimierz Sochaniewicz published his article Przyczynek czarów na Źmudzi $w$ XVII wieku (On Spells in Samogitia in the 17th Century), in which he featured a witchcraft case from $1672 .{ }^{37}$ In 1931, Juzef Jodkowski discussed the trial of a male witch based on a court case from 1691 in Hrodna. ${ }^{38}$ In 1936, P. Tučas published another witchcraft trial in his article Ragana ant laužo Ukmergëje (A Witch on the Bonfire in Ukmergè). ${ }^{39}$ In 1937, Akvilis Augstkalnis featured several protocols of the interrogation of people accused of witchcraft from the late 16th century in his article Tilžés lietuviu burtai XVI a. teismo aktuose (On the Spells of Lithuanians from Tilžè in 16th-Century Legal Acts). ${ }^{40}$ Pranė Dundulienė wrote about the torture and punishment of witches in popular science articles from the $1950 \mathrm{~s},{ }^{41}$ where she identified witchcraft trial procedures as an expression of the class struggle. ${ }^{42}$

Konstantinas Jablonskis started collecting sources about witchcraft trials in 1931; however, his collection was only published in 1987. It was compiled by Rimantas Jasas, who also added several new cases. ${ }^{43}$ This source laid the foundations for more thorough studies of the phenomenon. Juozas Jurginis wrote an introduction to the work, ${ }^{44}$ and in 1984 he published his study entitled Raganu gaudymo šimtmetis (A Century of Witch-Hunting), ${ }^{45}$ where he used as yet unpublished trial collections. His work featured a brief discussion

36 Акты, издаваемые Виленскою археографическою комиссиею, t. VI, X, XVIII, XX (Вилна, 1865-1895). Археографический сборник документов, относящуихся к истории Северо-западной Руси, т. 1 (Вильна, 1867), т. 3 (1867), т. 6 (1869).

${ }^{37}$ K. Sochaniewicz, Przyczynek czarów na Źmudzi w XVII wieku, Lud, Serja 2, t. 1 (Lwów, 1922), pp. 125-135.

38 J. Jodkowski, O czarowniku Znaku na inkwizycji w Grodnie w 1691 r. (Lwów, 1932).

39 P. Tučas, 'Ragana ant laužo Ukmergèje', Lietuvos aidas, nr. 130 (1939 kovo 20 d.).

40 A. Augstkalnis, 'Tilžès lietuvių burtai XVI a. teismo aktuose', Tautosakos darbai, t. 3 (Kaunas, 1937), pp. 239-243.

41 P. Dundulienė, 'Siaubinga praeitis', Mokslas ir gyvenimas, no. 6 (1958), pp. 31-36; idem., 'Kelias ị laužą', Mokslas ir gyvenimas, no. 4 (1959), pp. 28-31.

42 P. Dundulienè, 'Siaubinga praeitis', p. 33.

43 Raganu teismai Lietuvoje, eds. K. Jablonskis, R. Jasas (Vilnius, 1987).

44 J. Jurginis, 'Raganų teismai', ibid., pp. 11-23.

45 J. Jurginis, Raganų gaudymo šimtmetis (Vilnius, 1984). 
on the nature of cases, and the course of the trial procedure was illustrated with excerpts from the files. Reasons for the persecution of witches were also given.

V. Kavolis associated the beginning of court procedures against witches with the greater emancipation of women in Lithuania in the 16th century, which in the view of authors from those times threatened the male-dominated world. ${ }^{46}$

N. Vèlius and R. Jasas have also discussed the content of witchcraft court cases from the 16th and 17th centuries. ${ }^{47}$ The article Ragana (The Witch) by G. Beresnevičius and T. Čaplinskas gives a brief but very concentrated and clear presentation of the problem of witchcraft. ${ }^{48}$ They begin with the emergence of the phenomenon and its spread throughout Europe. Witchcraft is viewed as a universal, not an imported, phenomenon, more characteristic of agrarian societies than cities. However, in their opinion, the measures used to recognise witches were adopted from Western Europe, but were expressed in a gentler way in Lithuania. Giedre Sabaityte attempted to look at witches as outcasts of society. ${ }^{49}$ She published several entries about spells from the first half of the 16th century from the books of the Kaunas city voigt. ${ }^{50}$ In 2013, Gitana Zujiene’'s article Theatrum poenarum Lietuvos raganu teismuose XVI-XVIII a. (Theatrum poenarum in Lithuania's Witchcraft Trials in the 16th to 18th Centuries) appeared, where she gave an analysis of civil court procedures, such as testing if someone was a witch, torture and punishment. ${ }^{51}$ She revealed the purpose behind such images as being to spread information and form public opinion. Meanwhile,

${ }^{46}$ V. Kavolis, Moterys ir vyrai lietuviu kultūroje, pp. 36-40.

${ }^{47}$ N. Vèlius, 'Raganų bylos Lietuvoje XVI a.', BRMŠ2, pp. 428-437; R. Jasas, 'Raganų bylos Lietuvoje XVI a.', ibid., pp. 425-428; R. Jasas, 'Raganų teismai Lietuvoje XVII a.', ibid., t. 3, (Vilnius, 2003), pp. 379-382.

${ }^{48}$ G. Beresnevičius, T. Čaplinskas, 'Ragana', pp. 557-573.

49 G. Sabaitytè, 'Raganų 'medžioklès' atgarsiai XVI-XVII a. pirmos pusès Kaune', Kauno istorijos metraštis, t. 8 (Kaunas, 2007), pp. 279-296; idem, 'Raganų tapimas 'užribio žmonėmis' Lietuvos Didžiojoje Kunigaikštystejje', Lietuvos istorijos metraštis 2009/1 (Vilnius, 2010), pp. 69-88; eadem, Užribio žmonès Lietuvos Didžiosios Kunigaikštystès visuomenèje. Daktaro disertacija (Kaunas, 2010).

${ }^{50}$ G. Sabaitytè, 'Raganų 'medžioklès' atgarsiai', pp. 293-296.

${ }^{51}$ G. Zujienè, 'Theatrum poenarum Lietuvos raganų teismuose XVI-XVIII a.', Ministri historiae. Pagalbiniai istorijos mokslai Lietuvos Didžiosios Kunigaikštystès tyrimuose, ed. Z. Kiaupa, J. Sarcevičienè (Vilnius, 2013), pp. 343-362. 
Aivas Ragauskas highlights in his research the necessity of rehabilitating the victims of witcheraft trials. ${ }^{52}$

Historians from neighbouring countries have also taken an interest in Lithuanian witchcraft trial procedures. Many of them stressed the major influence of relics of paganism on the concept of witchcraft in the Grand Duchy of Lithuania. ${ }^{53}$ In the opinion of the Belarusian historian Vitali Byl, Lithuanian secular judges did not believe in the existence of a harmful witch-based sect. ${ }^{54}$ Uladimir Lobach drew attention to the fact that the property of the accused and prosecuted was not confiscated during the trial, as was the case in Western Europe. ${ }^{55}$ In addition, it was the plaintiff who had to cover the court costs. ${ }^{56}$ In Byl's opinion, more similarities between court procedures started to appear only in the second half of the 17th century, when courts sought to expose other members of the witch community. ${ }^{57}$ Lobach, however, claims that from the second half of the 17th century, a typical Inquisition-style court

52 The conversation with Prof. A. Ragauskas was published by M. Kniežaitè, 'Raganas prisimenant ne iš pasakų', Lietuvos žinios (2015 liepos 22), http://lzinios. 1t/lzinios/Mokslas-ir-svietimas/raganas-prisimenant-ne-is-pasaku/205985 (accessed on 20160318$)$.

53 Ү. Лобач, 'Чараўніцтва на Беларусі на тле сярэднявечных судовых працэсаў’, Kpыy̆я. Crivica. Baltica. Indogermanica, no. 1 (1998), pp. 87-99; idem, 'Burtininkavimas krivičių žemèse', Liaudies kultūra, no. 3 (1999), pp. 53-55; idem, 'Да механізму чарадзейскіх працэсаў у сярэднявечнай Беларусі: на прыкладзе справы палачаніна В. Брыкуна (1643 г.)', Беларускі горад у часе i прасторы: 500 гадоў Полаикай магдэбургіi (Наваполацк, 2001), pp. 52-59.; idem, 'Вядзьмарскі працэс 1691 г. у Гародні: да тыпалогіi чарадзейскіх спраў у сярэднявечнай Беларусі’, Культура Гродзенскага рэгіёну: праблемы развіция ва ўмовах поліэтнічнага сумежжа (Гродна, 2003), pp. 20-25; idem, 'Чараўнік', Беларуская міфалогія (Мінск, 2006), с. 549; В. Быль, 'Асаблівасці ведаўскіх працэсаў на землях Вялікага Княства Літоўскага ў XVI-XVIII стст.', Европа 2010: глобальное и локальное (2011), pp. 84-92; M. Pilaszek, 'Litewskie procesy czarownic', Odrodzenie i Reformacja, t. 4 (2002), pp. 7-35. A more widely known work by this author that has been the focus of some contradictory assessments is her monograph: M. Pilaszek, Procesy o czary w Polsce $w$ wiekach XV-XVIII (Kraków, 2008). Reviews of this monograph: J. Wijaczka, 'Procesy o czary w Polsce w epoce wczesnonowożytnej’, Kwartalnik Historyczny, R. XCVI, z. 3 (2009), pp. 113-127; J. Adamczyk, Procesy o czary w Polsce $w$ wiekach XV-XVIII, Małgorzata Pilaszek (Kraków, 2008), Przeglad Historyczny, 100/4 (2009), pp. 839-843.

${ }^{54}$ В. Быль, 'Асаблівасці ведаўскіх працэсаў', р. 87.

${ }^{55}$ Ү. Лобач, ‘Чараўніцтва на Беларусі', р. 6; В. Быль, ‘Асаблівасці ведаўскіх працэсаў’, p. 91.

${ }^{56}$ Ibid., p. 91.

${ }^{57}$ Ibid., p. 88. 
procedure already operated in the GDL that was no different to its precedent in Western Europe. ${ }^{58}$ The Polish historian Malgorzata Pilaszek highlighted the economic reasons for the persecution of witches. She gives a brief discussion of the court procedures and punishments. ${ }^{59}$ A monograph by the Ukrainian historian Katerina Dysa about witcheraft in the Ukrainian lands in the 17th and 18th centuries looks at certain aspects of the witchcraft trial process, in order to reveal its particularities. She questions the scale and meaning of torture, and compares the law with its realisation in practice. However, she limits herself to Magdeburg Law and the lands that belonged to the Kingdom of Poland. ${ }^{60}$ Michael Ostling's monograph raises the question of how images and ideas from the centre reach the periphery, and how they are adapted and modified. ${ }^{61}$ For his research, he selected the image of the witch and witchcraft trials in the Kingdom of Poland in the 16th to the 18th centuries. The author did not refer to the situation in the Grand Duchy of Lithuania, only illustrating the state of affairs here with a reference to the already-mentioned article by Pilaszek. ${ }^{62}$ But his observations about general Slavic and Baltic-Slavic elements in the image of the witch are very interesting.

\section{I.3. Sources}

The sources referred to in this paper can be divided into three groups. The first are secular legal acts that set the regulations for witcheraft case deliberations in court. Byl has pointed out that a specifically Lithuanian legal basis for these procedures was not created, noting it as one of the particularities of the Lithuanian witchcraft trial process. ${ }^{63}$ However, the courts of the Grand Duchy of Lithuania

${ }^{58}$ Ү. Лобач, 'Чараўніцтва на Беларусі', р. 8.

${ }^{59}$ M. Pilaszek, 'Litewskie procesy czarownic', pp. 7-35.

${ }^{60} \mathrm{~K}$. Диса, Історія з відьмами. Суди про чари в украӥнських воэводствах Речі Посполитої XVII-XVIII столиття (Київ, 2008). A supplemented monograph by the same author in English: K. Dysa, Witchcraft Trials and Beyond: Trials for Witchcraft in the Volhynian, Podolian and Ruthenian Palatinates of the PolishLithuanian Commonwealth in the Seventeenth and Eighteenth Centuries (Budapest, 2011).

${ }^{61} \mathrm{M}$. Ostling, Between the Devil and the Host: Imagining Witchcraft in the Early Modern Poland (Oxford, 2011), pp. 5-6.

${ }^{62}$ Ibid., p. 8.

${ }^{63}$ В. Быль, 'Асаблівасці ведаўскіх працэсаў’, p. 89. 
made do quite well with their existing laws. The Statute of Lithuania indicated which courts had to deliberate over witchcraft cases, and regulated criminal procedures in the country in general. ${ }^{64}$ In addition, the Statute allowed for the use of other laws, if the need arose. It was referred to in the castle, land and sub-chamber courts. Saxon legal acts regulated laws in Magdeburgian cities, namely, the law of the Saxon land, the 'Saxon mirror' (Speculum Saxonum), and law of the Saxon city (Weichbildrecht). ${ }^{65}$ The editions by Bartłomiej Groicki were most popular. ${ }^{66}$ The law code published in Germany in 1532 by Emperor Charles V Constitutio Criminalis Carolina was also used, which regulated punishment for convictions for witchcraft. ${ }^{67}$ The constitutions of the sejms of Poland and the Polish-Lithuanian Commonwealth of 1543, 1563-1565 and 1776 outlined the competencies of secular and ecclesiastical courts in witcheraft trials. ${ }^{68}$

The second group of sources are the witchcraft case files themselves. The research was conducted based on the files mentioned in the historiography section. They span both the territory of present-day Lithuania (the cities of Kaunas, Merkine and Alytus, the Duchy of Samogitia, the powiats of Vilnius, Kaunas, Ukmerge and Upyte, the

${ }^{64}$ Статут Вялікага Княства Літоўскага 1588, IV.30; IV.32-35, 39, 47-58, $76-81,86$ and other articles from this chapter. Also Chapter XIV where the articles discuss the criminal's persecution, arrest, imprisonment and torture.

${ }^{65}$ In Poland, these legal acts were published for the first time in 1506 in Łaski' code: J. Łaski, Commune incliti Polonie Regni priuilegium constitutionum et indultuum publicitus decretorum (27 I 1506, Cracovia). The Polish lawyer Mikołaj Jaskier released a separate work in Latin in 1535: M. Jaskier, Juris Municipalis Maideburgensis (Cracovia, 1535). The Polish translation by Paweł Szczerbic was released in 1581: P. Szczerbic, Speculum Saxonum albo prawo saskie i magdeburskie porządkiem abecadła z łacińskiego i niemieckich exemplarzów zebrane (Lwów, 1581); idem, Jus municipale, to jest prawo miejskie magdeburskie nowo z tacińskiego $i$ niemieckiego języka z pilnością i wiernie przełożone (Lwów, 1581). A new edition of this book: P. Szczerbic, Jus municipale, to jest prawo miejskie magdeburskie nowo z łacińskiego i niemieckiego języka z pilnościa $i$ wiernie przełożone, wyd. G.M. Kowalski (Kraków, 2011).

${ }^{66}$ P. Groicki, Artykuty prawa majdeburskiego, które zowia Speculum Saxonum (1558); idem, Porządek sądów i spraw miejskich prawa majdeburskiego w Koronie Polskiej (1559); idem, Postęek sąów około karania na gardle, (1559).

${ }^{67}$ Каролина - уголовно-судебное уложение Карла V, перевод С.Я. Булатов (Алма-Ата, 1967).

${ }^{68}$ Volumina legum, I (Petersburg, 1859), s. 578-579. Alongside the state legal acts, in Poland in 1769 a book Praktyka Kryminalna (Criminal Practice) was realised by Culm Lawer Jakub Czechowicz. It also contains a separate section on witchcraft trials. However, as this work was not mentioned in Lithuanian court files, it has not been used in this study. 
Šiauliai Economy, ${ }^{69}$ and the estate courts of Žagare and Joniškis), and the territory of present-day Belarus, which was then part of the GDL (the cities of Polotsk and Kobryn, and the powiat courts of Ašmena, Breslau, Lida, Hrodna, Novahrudok, Minsk, Slonim, Pinsk and Vitebsk).

The third group of sources are documents from the Holy See, synods of Lithuanian bishops, bishops and monks. The most important one directly related to Lithuania was the papal bull of Gregory XV of 1623 Omnipotentis Dei, whose provisions were announced in Samogitia in 1643 by Bishop Jurgis Tiškevičius. ${ }^{70}$ This was the final papal bull directed against witches. Later documents from the Roman curia tried to ease the situation in witchcraft trials, in order to curb the meaningless torment caused by fear, fanaticism, and sometimes simply mere deduction. The Instructio circa judicia sagarum (henceforth, Instructio) was issued in Rome in 1657, and re-issued in Krakow in 1670, and in Vilnius in 1721, at the initiative of Bishop Konstantinas Kazimieras Bžostovskis (Konstanty Kazimierz Brzostowski). ${ }^{71}$ It gave a detailed explanation of the procedure for such trials, including interviews, the collection of evidence and sentencing, rejecting the established methods for ascertaining who might be a witch. The Lithuanian Catholic Church's relationship with spells and witches becomes evident when we examine the resolutions of bishops' synod and bishops' pastoral letters. ${ }^{72}$ The position of monks is revealed in mission reports and annual letters. ${ }^{73}$ This group of sources also features the mentioned book by Sprenger and Institor, Malleus Maleficarum. It was translated into Polish in $1614 .{ }^{74}$

${ }^{69}$ In this sense, an Economy was an alliance of royal estates.

${ }^{70}$ Baltu religijos ir mitologijos reliktai, p. 203.

${ }^{71}$ Instructio circa iudicia sagarum, iudicibus, eorumq; consiliariis accomodata (Romae primum, 1657); Iterum pro bono publico (Cracoviae, 1670). Nunc vero (Vilnae, 1721).

${ }^{72}$ Extracts from resolutions made at the Diocese of Samogitia synod of 1752 have been published in J. Lebedys, Lietuviu kalba XVII-XVIII a. viešajame gyvenime (Vilnius, 1976), pp. 201-202. Extracts from resolutions made at synods in Samogitia and Vilnius in the 17th-18th centuries, and extracts from bishops' letters regarding witchcraft have been published in Baltu religijos ir mitologijos reliktai, pp. 112-113, 187-191, 195-196, 202-203, 289-290, 358-362, 370-372.

${ }^{73}$ Baltu religijos ir mitologijos šaltiniai, t. I-IV, sud. N. Vèlius (Vilnius, 19962005); Baltu religijos ir mitologijos reliktai Lietuvos Didžiojoje Kunigaikštystèje (XIV-XVIII a.), ed. V. Ališauskas (Vilnius, 2015).

${ }^{74}$ Młot na czarownice [...], przez Stanisława Ząbkowica (Kraków, 1614). 


\section{I.4. Competency of the courts}

In the first half of the 13th century, alongside canonical courts, Pope Gregory IX founded the Holy Office in the struggle against heretics. In 1318, an inquisitor from the Holy Office was appointed in Poland. In 1424 in the Edict of Wielun, Jogaila, the King of Poland and Supreme Duke of Lithuania, declared heresy an offence against the dignity of the king (crimen laesae maiestatis). He indicated that secular officials and courts had to assist inquisitors in the struggle against heresy. ${ }^{75}$ The secular courts had to provide the functions of imprisonment, presentation of the prisoner, and execution of the punishment. The Inquisition did not have the same meaning here as it did in Western Europe. Until the middle of the 16th century, witchcraft trials in Poland were usually presided over by a bishop, rather than an inquisitor, as witchcraft was not considered heresy here, i.e. witches were not accused of collaboration with the Devil. While canonical courts presided over witcheraft trials in the 15th and the first half of the 16th century, they did not resort to torture, and the verdicts were relatively humane. ${ }^{76}$ There were instances of death sentences, but only when the case reached the secular, usually Magdeburgian, court. ${ }^{77}$ It could be that as Lithuania belonged to the Polish archdioceses of Gniezno and Lviv, witchcraft cases were deliberated in the Vilnius, Samogitian, Lutsk and Kyiv episcopal courts. ${ }^{78}$ In the cities, these cases could have been deliberated in accordance with Magdeburg Law.

The constitution from the Polish sejm of 1543 foresaw that matters of faith, heresy, schisms, apostasy, vile language (swearing), sacrilege and spells came within the competence of the canonical courts. ${ }^{79}$

${ }^{75}$ Volumina legum, I, p. 86. The edict was primarily aimed against the Hussites and their supporters. In 1199, Pope Innocent III compared heresy to the secular crimes of injury and treason against the ruler (crimen laesae maiestatis), which were punishable by death (E. Graham-Leigh, The Southern French Nobility and the Albigensian Crusade (Woodbridge, 2005), p. 61), Volumina legum, II, p. 622.

${ }^{76}$ K. Koranyi, 'Czary i gusla przed sądami kościelnymi w Polsce w XV i pierszej połowie XVI wieku', Lud, r. 26 (1927); J. Adamczyk, 'Czary i magia w practyce sądów kościelnych na ziemiach polskich w póżnym średniowieczu (XVpołowa XVI wieku)', Karolińscy pokutnicy i polskie średniowieczne czarownice, wyd. M. Koczerska (Warszawa, 2007), pp. 91-260.

${ }^{77}$ Sz. Wrzesiński, Inkwizycja na ziemiach polskich (Zakrzewo, 2009), p. 175.

${ }^{78}$ Kyiv and most of the Diocese of Lutsk which belonged to the Lviv Archdiocese were joined to the Kingdom of Poland in 1569.

${ }^{79}$ Volumina legum, I, pp. 578-579. 
However, it did allow the secular court to handle witchcraft cases if the plaintiff had incurred material losses as a result of spells. Some researchers are of the opinion that this constitution applied in Lithuania as well. ${ }^{80}$ In the opinion of M. Pilaszek, the resolutions from the sejms of 1563-1565 had a deciding role in witchcraft trial procedures in Poland. ${ }^{81}$ It was then that the Church lost all influence in witchcraft trials. ${ }^{82}$ It was prohibited from resorting to secular courts for the interrogation, imprisonment and punishment of the accused.

The Third Statute of Lithuania also attributed witcheraft cases to the secular courts. In Chapter 4 Article 30, witchcraft is mentioned along with violent crimes, such as robbery of nobles' homes, violent acts against the Catholic Church, rape, roadside robbery, thievery, forgery, arson and poisoning. These crimes were under the jurisdiction of the palatine, starosta and estate manager courts. ${ }^{83}$

As the Inquisition as we know it did not take place in Lithuania, there were no professional witch-hunters here who would travel from place to place and organise processes for the exposure of witches. Each estate or class had its own laws, so those accused of witchcraft would be tried in different courts. Nobles suspected of witchcraft, or nobles who refused to judge their own people suspected of witchcraft, would be called to the castle court, which operated in accordance with the Statute of Lithuania. The peasants' cooperative court operated in villages, where custom law held great significance. Yet the competency of this court to preside over witchcraft cases was questioned on occasions. ${ }^{84}$ Serfs would be judged in estate courts. ${ }^{85}$ The owner of the estate, its manager or an appointed regent would preside over the estate court. Often, nobles chosen from the surrounding area would participate in such hearings. Estate law consisted of a combination of custom law and the will of the estate's owner. In Magdeburgian cities, which followed Saxon city law, these cases were heard by the courts of the voigt (vaitas) and

${ }^{80}$ G. Beresnevičius, T. Čaplinskas, 'Ragana', p. 567.

${ }^{81}$ M. Pilaszek, Procesy o czary w Polsce, p. 213.

${ }^{82}$ Volumina legum, II, p. 622.

${ }^{83}$ Статут Вялікага Княства Літоўскага 1588, IV.30.

${ }^{84}$ Raganu teismai Lietuvoje, p. 29.

${ }^{85}$ Serfs were completely under the jurisdiction of their masters as early as in 1447 , in accordance with the privilege of Casimir Jagiellon. 
benchers (suolininkai), and sometimes by joint magistrate courts (with the participation of the burgomaster, councillors, the voigt and benchers).

If until the middle of the 17th century the highest Lithuanian Church dignitaries urged secular government (secular courts) to be the deciding voice in witchcraft cases, then from the second half of the 17th century, the Church went to great efforts to restore the influence it had lost in such cases. For example, in the resolutions of the Second Synod of the Diocese of Samogitia of 1639, priests were encouraged not just to rest on the advice of the canonical court, but also to pay heed to the secular government's support. ${ }^{86}$ At the Third Synod in 1643, the Samogitian bishop J. Tiškevičius announced the papal bull of Gregory XV Omnipotentis Dei, which urged the persecution of sorcerers and witches, and to present those accused of doing harm to property, health or life to the secular court. However, the court was also warned not to overstep the boundaries set down by law during torture. ${ }^{87}$ That same year, the Vilnius Synod also urged the clergy to punish and eliminate sorcerers and witches from the community of the faithful. Yet secular courts were not allowed to torture those suspected of witchcraft. ${ }^{88}$ Nevertheless, the secular courts functioned at their own discretion in such procedures, which is why in 1672, the bishops demanded that the ruler restrict the competency of secular courts in witchcraft trials. ${ }^{89}$ In 1700, the Vilnius bishop instructed the clergy not to assume jurisdiction, as witchcraft cases had to be handled by the canonical court, especially when witches condemned God, worshipped the Devil and renounced their faith. ${ }^{90}$ In 1710, Bishop Brzostowski, resting on Instructio from Rome of 1657, also demanded that such cases be left to the canonical court. ${ }^{91}$ In 1717, the Vilnius Synod announced that secular verdicts in witchcraft trials were criminal. ${ }^{92}$ The Samogitian bishop Juozapas Mykolas Karpis, in his pastoral letter of 1737, referring to the Constitution of 1543, forbade secular members of the community

\footnotetext{
${ }^{86}$ Baltu religijos ir mitologijos reliktai, p. 195.

${ }^{87}$ Ibid., p. 203.

88 J. Putek, Mroki średniowiecza, p. 209.

${ }^{89}$ Ibid., p. 210.

90 G. Beresnevičius, T. Čaplinskas, 'Ragana', p. 569.

91 Baltu religijos ir mitologijos reliktai, pp. 283-284.

92 Ibid., pp. 289-290.
} 
from torturing, drowning or burning those accused of witchcraft. The bishop was most alarmed that the uneducated masses usually held someone to be a witch who was not actually one. Torturing and burning suspected individuals willingly and independently (without the Church's knowledge) was identified as a serious and deadly sin. In such events, it was forbidden to extend forgiveness, except in the face of death. ${ }^{93}$ The Vilnius Synod of 1744 even threatened secular organisers of witchcraft trials with excommunication. ${ }^{94}$ In 1752, the Samogitian bishop Antanas Tiškevičius declared that on receiving an announcement about suspected witchcraft, he would appoint a priest to examine the situation. If the accusations proved to be well founded, only then would the suspect be handed over to the secular court. ${ }^{95}$ Taking into consideration the demands of the clergy, in 1703 Augustus II, and in 1745 Augustus III, banned secular members of society from examining cases of witchcraft and spell-casting. ${ }^{96}$ However, all these demands and restrictions had little impact in practice. From our existing sources, we cannot say with any certainty to what extent the clergy directly contributed to the organisation of witchcraft trials. Alongside the entries from monastic reports written up after missions about people diverted from engaging in spells and witchcraft through teaching and warnings, sometimes there is mention of the souls of the damned, saved for God after their death, having heard their confessions and been witness to their remorse. ${ }^{97}$ So, having been informed of the accusations, the monks would agree with the secular court verdicts and offer the damned the last rites. However, there were cases where monks actually saved 'witches' that had been convicted as such in secular courts. ${ }^{98}$ This continued until the Constitution of the 1776 Sejm banned torture throughout the entire Polish-Lithuanian Commonwealth as a means of eliciting an admission, as well as the death sentence in witchcraft trials. ${ }^{99}$ However, illegal procedures still occurred for some time.

\footnotetext{
93 Baltu religijos ir mitologijos reliktai, p. 361.

${ }^{94}$ Ibid., p. 371.

95 J. Jurginis, Raganu gaudymo šimtmetis, p. 21.

${ }^{96}$ G. Beresnevičius, T. Čaplinskas, 'Ragana', p. 569.

${ }^{97}$ Baltu religijos ir mitologijos reliktai, pp. 339, 341.

${ }^{98}$ Ibid., pp. 217, 246, 265, 282, 291.

99 Volumina legum, t. VIII, pp. 546-547.
} 


\section{I.5. The development of accusations of witcheraft}

The earliest information we have about witchcraft trials in the GDL comes to us from the first half of the 16th century. A poem by Mikołaj Hussowczyk (Nicolaus Hussovianus) written in around 1523 called 'Hymn about the Bison' mentions elements of paganism that were widespread in Lithuania, as well as sorcery, the floating of a witch and her burning. ${ }^{100}$ A notice of the palatine Ivanas Bogdanovičius Sapiega dated 5 August 1532 concerns the rehabilitation of Marija Nesterovna, who had been accused of witchcraft and driven from the city and lands of Vitebsk. ${ }^{101}$ Sabaityte has compiled all the accusations of witchcraft in made in Kaunas in 1543 in a register. ${ }^{102}$ However, the earliest entries usually only record the suspected use of spells or the fact of punishment. Finer details on the course of events are not available.

The first accusations of witchcraft in Lithuania were heaped upon herbalists and midwives, regardless of the fact that the religious literature of the day acknowledged the possibility of having God's gift of knowing about plants and herbs and their powerful properties. ${ }^{103}$ If they failed to heal someone or help during a birth, these people would be accused of making their patients fall even more ill or causing their death with their spells. For example, in 1552 a resident of Kaunas called Jadvyga was accused of telling a spell to Elena of Kedainiai, so that she might have a normal birth without any complications. ${ }^{104}$ In 1563, a herbalist from Kaunas called Kotryna was interrogated. ${ }^{105}$ In 1566, also in Kaunas, the witch Ulijona was burned, allegedly for using herbs to poison people. ${ }^{106}$ The herbalist Motiejus Juknevičius was interrogated in $1580 .{ }^{107}$ The extent of accusations of witchcraft spread further in the late 16th century. It encompassed people who had actually attempted to cast spells, those who carried out pagan rituals, and those whose behaviour appeared strange or could not be understood by others.

100 M. Husovianas, Giesmè apie stumbro išvaizda, žiauruma ir medžioklę (Vilnius, 1977).

101 Беларускі архіў (XV-XVI cm.), т. 2, (Менск, 1928), p. 96.

102 G. Sabaitytė, 'Raganų 'medžioklès' atgarsiai', p. 293.

103 Postępek prawa czartowskiego, p. 120.

104 Raganu teismai Lietuvoje, p. 73.

105 Ibid., p. 74.

106 Ibid., p. 76.

${ }^{107}$ Ibid., p. 77. 
From the case files, we learn that for a long time witches worked alone in Lithuania, trusting only their powers, and not relying on any collaborators, least of all the Devil. They used various herbs, saliva, hair, earth from their shoes, parts or items of clothing, and dead animals or parts of them, for their spells. Two cases mention specially constructed 'dolls'. Only in one case was a woman accused of intending to use the exhumed and dried body of a child for her spells. ${ }^{108}$ Collaborators in witcheraft barely rate a mention in case files from the 16th century. In 1566, Julijona, who was interrogated in the Kaunas powiat, named another five women. ${ }^{109}$ Gertrūda Jakutaite, who was tortured in Samogitia in 1602, divulged her 'teacher'. ${ }^{110}$ The number of such cases increased from the second half of the 17 th century. Of the total of 128 case files, entries and complaints published in the book Raganu teismai Lietuvoje (Witchcraft Trials in Lithuania), only 12 (less than 10\%) mention the witch's collaboration with the Devil. The earliest mentions of such collaboration are especially interesting. For example, in 1563 in Kaunas, the herbalist Kotryna, who was mentioned earlier, admitted that the Devil had helped her learn about herbs and how to use them to heal. But she added that the herbs did not harm but helped people. ${ }^{111}$ A similar admission came from Raina Gromykiene in 1631 at the Novahrudak castle court. ${ }^{112}$ Nevertheless, the court decided that in learning these things she had bad intentions. We know of three cases from the second half of the 17th century where the purpose of collaborating with the Devil, to cause harm, is clearly highlighted. ${ }^{113}$ The majority of cases (seven in total) are from 1720-1780, ${ }^{114}$ though they make up only around $16 \%$ of all witchcraft cases from the 18th century.

So from the second half of the 18th century, we see the greater influence on courts in the GDL of a concept of witchcraft that predominated in Western Europe, by which suspects are more often accused of collaborating with the Devil, and where the goal is to find out about a potential network of witches operating within the region. There are more images of witches' gatherings, the denial of God, and obedience to the Devil.

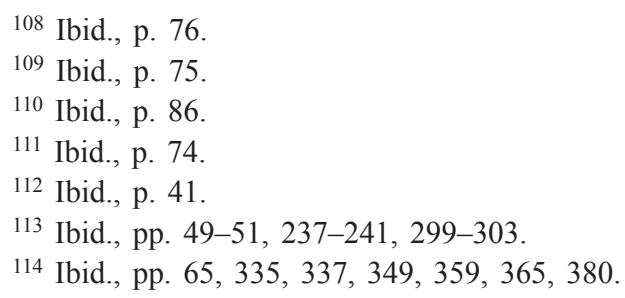




\section{The court procedure}

In Western Europe, crimes were regarded as either ordinary (crimina ordinaria) or extraordinary (crimina exepta). Witchcraft, along with high treason and offending the dignity of the king, were among the latter. In the event of such crimes, the court had exceptional powers. The duration of trials was quicker, and stricter forms of imprisonment and torture could be used. In Lithuania meanwhile, as we have seen, witchcraft was considered to be among the crimina ordinaria (a raid on a noble's home, robbery, theft, etc). There are also entries in these cases which read that 'witches must be punished for witchcraft as thieves are punished for theft.' 115

In Western Europe, witchcraft cases were resolved by both inquisitors and secular courts. In the courts of the Inquisition, the entire court procedure was the judge's fight with the Devil, who was said to control the accused. The judge's goal was to force the Devil to leave the accused, so that she could admit her guilt and accept her punishment. Although it was said that the witch could not harm the person carrying out social justice by persecuting her, ${ }^{116}$ and that God himself protected the executors of heavenly justice, ${ }^{117}$ the judge still had to take certain safety measures. ${ }^{118}$ We also come across some self-preservation elements from witchcraft trials in Lithuania. For example, sometimes the accused would be sprinkled with Holy Water, so that she might not cast any more spells or curses, ${ }^{119}$ although such cases were very rare. In Lithuania, the struggle against the Devil was also not really stressed.

The witchcraft trial procedure in Lithuania consisted of several main parts: the accusation, serving a summons, interrogation, ordeal, imprisonment, torture, passing the verdict, and punishment. An appeal was also possible. Incidentally, all these stages only existed in Magdeburgian and castle courts. The procedure in cooperative and estate courts was usually much shorter, and often more violent.

\footnotetext{
115 Ibid., pp. 176, 177.

${ }^{116}$ Молот ведьм, рр. 182, 185.

117 Ibid., p. 187.

118 Ibid., pp. 75-76, 279, 371.

119 Raganu teismai Lietuvoje, p. 34.
} 


\section{II.1 The accusation}

The actual accusation of engaging in witchcraft was very different in Lithuania and Western Europe. Malleus Maleficarum distinguished three ways of making an accusation. The first was a personal presentation of the accusation. The accuser had to give incontrovertible evidence of wrongdoing, otherwise they could be brought to trial for defamation. ${ }^{120}$ The second was denunciation, where the declarer simply shared their suspicions or hearsay to the judge. ${ }^{121}$ Such rumours were often serious enough grounds to open a case file. The third was an investigation started at the initiative of the inquisitors themselves, who had heard of witchcraft in a certain location. Malleus Maleficarum recommended the last two means, as the first one, in the authors' opinion, risked the revenge of the witch or her collaborators, as much as for the plaintiff, if they failed to prove her guilt. ${ }^{122}$ In the case of a denunciation, the accusers and witnesses usually remained anonymous. ${ }^{123}$ In Lithuania meanwhile, the first method was used. A court case would begin as soon as a plaint from an injured person was received. Usually, the plaint would be formulated on the basis of loss of life, worse health as a result of the experience, or material losses due to spells. The plaint had to be entered into the court books. In order to open a court case, the plaintiff had to procure a summons that would be presented to the accused by a vozny (woźny). ${ }^{124}$ The summons procedure in noble law in the GDL was regulated in the Statute. ${ }^{125}$ A summons had to be presented no later than four weeks before the court session. It outlined who, and on what grounds, was summoning the accused to court. A summons was valid for one specific court session. If a person was arrested at the scene of the crime, 'caught red-handed', then a summons was not necessary. If a noble being summoned did not come to the court hearing, or failed to present his accused peasant, he could be punished with banishment. A similar practice

${ }^{120}$ Молот ведьм, р. 341.

${ }^{121}$ Ibid.

122 Ibid., p. 348.

123 Ibid., pp. 342-343.

${ }^{124} \mathrm{~A}$ vozny was a court official who presented court summons papers, inspected the scene of the crime, made an assessment of the damage, and reported this information to the court. Sometimes he would carry out court verdicts as well.

125 Статут Вялікага Княства Літоўскага 1588, IV. 18-24. 
applied in Magdeburgian courts. There were often cases in castle and Magdeburgian courts where the aggrieved party would only enter their plaint into the court books, without necessarily proceeding with opening a case file. A summons was not required in estate or cooperative courts. After the declaration of a plaint, the accused would be brought to court by their master, or on the instruction of an estate official.

\section{II.2. The court inquiry}

Malleus Maleficarum recommended organising the inquiry of witches on religious feast days, during Mass, or amid the ringing of church bells, so that it would be more difficult for the Devil to influence the accused. This has not been noticed in Lithuanian witchcraft trials. Court hearings followed a regular order. For example, the castle court sat in the first two weeks of every month. A cooperative court was assembled when needed, while a noble would organise a court hearing at his own discretion, not taking religious feasts into consideration.

Malleus Maleficarum outlined the right of the accused to have someone act in her defence, a lawyer. Yet he would be appointed by the judge, and not someone the accused selected herself. The lawyer had to help carry out the court procedure, and most importantly, to be sure not to defend the accused too vigorously, so that he might not be seen as a suspect himself, or as a protector of heretics. ${ }^{126}$ Usually, the accused did not have anyone to act in their defence. In the Lithuanian castle court, however, if the accused could not defend themselves, they could select their own procurator. If the accused was not very wealthy and could not afford to hire a procurator, the court had to appoint one. ${ }^{127}$ In fact, this point was sometimes ignored. Sometimes a noble would hire a defender for his peasant. Unlike in Western Europe, in Lithuania the procurator carried out the functions of a defence lawyer, arguing the basis of the plaintiff's evidence, and trying to give rational explanations for their client's actions, which the plaintiff thought was a spell. Such procurators could also make the court case drag on, arguing various procedural aspects. For example, in October 1631, Jurijus Moras, the defender of Raina Gromykiene, who received a death sentence

126 Молот ведьм, pр. 354-356.

127 Статут Вялікага Княства Літоўскага 1588, IV, pp. 56, 57. 
at the Novahrudak castle court, made an appeal to the Supreme Tribunal, and proved that the verdict was invalid, as it was not passed in accordance with the set procedures, i.e. the court trial was held without an official summons. The Tribunal repealed the castle court's verdict, but ordered to bring the same case to trial again. ${ }^{128}$ In cooperative and estate courts, suspected peasants and serfs rarely had a defence lawyer.

The main forms of evidence, according to Malleus Maleficarum, depended on how obviously the crime was manifested. Public threats, for example, were considered a form of evidence, as was the same kind of evidence from several witnesses, and the witch's own confession. ${ }^{129}$ Evidence would be collected by the inquisitor. In Lithuania, it was the plaintiff who had to procure court evidence to support his claim. To illustrate this, here are some examples where public threats were taken as evidence. ${ }^{130}$ Usually two or three witnesses in court were enough. However, the more witnesses there were who could swear they were telling the truth, the more believable the accusation became. For example, in 1646 in the Kupiškis starosty, two women were accused of witchcraft, but did not confess at the court inquiry, nor during torture. Then, 40 men from the village declared that they were ready to testify that the women were indeed witches. The estate court decided to accept the oaths of seven peasants, and, taking into consideration that neither relatives nor close family members were prepared to defend the accused, it ruled that the women were guilty and they were convicted. ${ }^{131}$ In order to ensure that false testimonies could not be made, Malleus Maleficarum foresaw that witnesses could not be mortal enemies of the accused. ${ }^{132}$ Meanwhile, in 1657 Instructio recommended that courts take a very close and critical view of witnesses' testimonies. For example, in the event of the victim's illness or death, Instruction recommended that a competent doctor be called in to confirm or deny the use of spells. ${ }^{133}$ The most frequently occurring 'spells'

${ }^{128}$ Археографический сборник документов, t. 3, pp. 129-140. Unfortunately, when the court file was heard for the second time, the woman could not be saved. She was convicted and burnt. Ibid., p. 164.

129 Молот ведьм, р. 351.

${ }^{130}$ Raganu teismai Lietuvoje, pp. 42, 45, 47, 53, 84, 212, 297.

131 Ibid., p. 226.

132 Молот ведьм, р. 326.

${ }^{133}$ Instructio circa iudicia sagarum, pages unnumbered. 
would be discussed, denying their magical power. ${ }^{134}$ Yet in reality, witnesses were rarely taken to be unreliable. After they had sworn to tell the truth, not even the procurator's speech that could give a logical explanation for the events held to be spells could influence the court's verdict. However, there were cases when a plaintiff could not find any witnesses. On 28 April 1692, at the court of the Šiauliai Economy supervisor's regent, two women accused of witchcraft were set free because no one could be found who was prepared to take a public oath and accuse them of the alleged crime. ${ }^{135}$

The court would decide which side had to swear against the other, based on the strength of the submitted evidence. Usually this would be the plaintiff. However, if both the plaintiff's and the witnesses' evidence appeared to the court insufficiently believable, and the accused was being brought to trial for the first time, she would be allowed to take a public oath in her defence as well. For example, Agnè Andriejaite, who was being accused of poisoning in 1631 at the Samogitia castle court, said that she had been instigated to cast spells by Sofija Stasyte, who had given her the herbs to do so. The plaintiff demanded that the girl be tortured; however, taking into consideration the fact that she had not been suspected of witchcraft anywhere before, the court allowed Sofija Stasyte and two other people to swear that she had not cast any spells, and had not taught others to do so. The court found her not guilty. ${ }^{136}$ There are several cases where, given a lack of evidence, the accused was allowed to swear in her own defence, along with several other respected members of the community. ${ }^{137}$ Sometimes a public oath alone was enough to acquit underage people accused of witchcraft. ${ }^{138}$ Such oaths leading to acquittal became especially popular in the mid-18th century, when attitudes towards witchcraft trials were changing. ${ }^{139}$ Malleus Maleficarum also foresaw the possibility of the accused taking a public oath of her innocence when the evidence against

${ }^{134}$ For example, it was said that the clumps of feathers often found among quilts, bundles of raw flax or wool felt were not sewn-up spells but had occurred naturally due to prolonged use or the manufacturer's fault.

135 Raganu teismai Lietuvoje, p. 52.

136 Ibid., p. 165.

137 Ibid., pp. 165, 183, 231, 275.

${ }^{138}$ Ibid., p. 61.

139 Ibid., pp. 70, 371. 
her was weak. ${ }^{140}$ The wordings of these oaths were very different. In Malleus Maleficarum, the accused would swear that she was not a heretic. In Lithuania, however, like the accusation, the oath made no mention of heresy. The accused simply swore that she had not caused any harm to the plaintiff's health, livestock or harvest.

\section{II.3. Witchcraft ordeals}

One of the forms of obtaining evidence in witchcraft trials were witchcraft ordeals, or tests. They were similar in nature to the 'Court of God' (iudicia dei), or trial by ordeal in the Middle Ages, where they were a form of punishment. Their essence lay in the idea that God would not allow anything bad to happen to a person who was truly innocent. However, in 1215 Pope Innocent III banned the clergy from participating in such ordeals, and in 1374 Pope Gregory XI announced that ordeals contravened the teachings of the Church. ${ }^{141}$ Checking 'God's will' experienced a resurgence in witchcraft trials, where it took on a different aspect. It was not a verdict, but one of the stages of the court inquiry meant to reveal certain characteristics attributed to witches. Most widespread were ordeals involving water, weight, needles, tears and fire.

The most popular ordeal involved water, or floating a witch. ${ }^{142}$ The point of this test was that water, as a source of cleanliness created by God, would be rejected by collaborators of the Devil, thus witches would not sink. In addition, it was believed that a witch who had powers given to her by the Devil would be lighter than other people and thus would not sink. ${ }^{143}$ The floating was always a public event, at which the whole community would gather. In Lithuania, the public would be not just observers, but participants as well. For example, on 15 May 1615, Sofija Jurgeliene, her son Gasiulis Jurgelaitis, and Tumelis Darandundènas Povilaitis, peasants

${ }^{140}$ Молот ведьм, p. 386. Here it is referred to as a canonical cleansing.

${ }^{141}$ The papal bull of Gregory XI Salvator humani generis (Avignon, 8 IV 1374).

142 The first witcheraft ordeals using water were mentioned in the Code of Hammurabi from 2000 BC. When witchcraft could not be proven, the accused was handed over to God's court: they would walk into a river and submerge themselves. However, here the result was the opposite: the guilty would drown and the innocent would float. A. Tamošaitis, J. Kairys, Hammurabio istatymas (Kaunas, 1938), pp. 31-32.

${ }^{143}$ R. Zguta, The Ordeal by Water (Swimming of Witches) in the East Slavic World, Slavic Review, 36/2 (1977), p. 221. 
from the village of Magūnai, were suspected of witchcraft and had to undergo a water ordeal. Other peasants prepared boats in the lake near their homes. The accused were tied up and lowered into the water one by one. They were each thrown into the water twice. They did not drown, and thus they were acknowledged as witches. ${ }^{144}$ Afterwards, the most morally upstanding person from among the peasants was selected, tied up and thrown into the water. He immediately sank to the bottom, and the crowd could only just revive him when they pulled him out. After such a spectacle, it was clear to everyone that the innocent drown. ${ }^{145}$ In 1646, in the village of Sipainiai, two women were handed over to the executioner for floating. In front of all the witnesses, they were floated one at a time, and they 'swam like ducks'. ${ }^{146}$ In Lithuania, this floating ordeal would often be repeated twice. After the first floating, an attempt was made to elicit a confession using different methods. In 1697, the kampininkas (lodger) Mikalojus Karalius, who was accused of witchcraft, was tested with water before torture and after torture, and he still did not confess. ${ }^{147}$ Sometimes, in order to stress the reliability of the ordeal, it was highlighted that the accused actually wanted to drown themselves, but simply could not sink. ${ }^{148}$

However, trying to prove that the accused was a witch by the water ordeal alone was not enough. Sometimes people who had floated would be released on grounds of insufficient evidence. ${ }^{149}$ The confirmation of witchcraft required an admission of guilt from the accused, or a public oath by the plaintiff and witnesses that was mentioned earlier.

In some European countries (the Netherlands, England and France), the water ordeal was recognised as inappropriate and banned in the late 16th or 17 th century. ${ }^{150}$ It was also condemned by the Church. However, an accused woman was floated in Poland in 1775 at the last witch trial, ${ }^{151}$ and in Lithuania in $1759 .{ }^{152}$

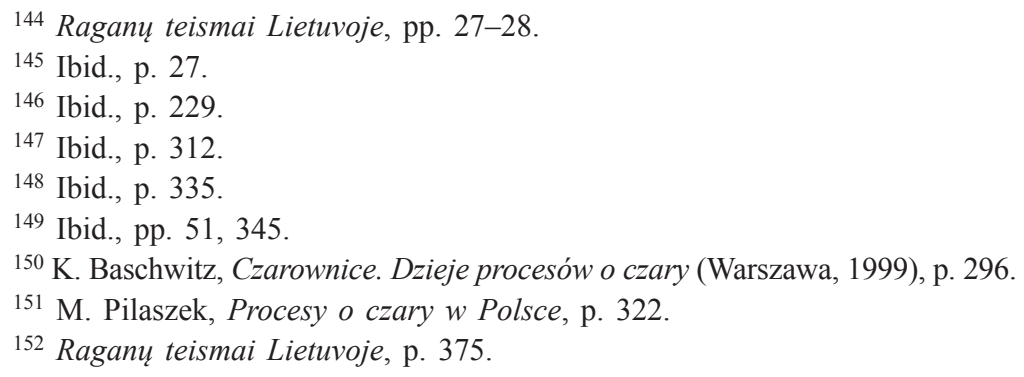


The simplest way of testing if someone was a witch was a full body inspection to search for marks of the Devil, red patches or moles. In Western Europe, during these inspections, the 'witch' would be stripped bare and all her hair would be shaven off. This stripping procedure is not mentioned in Lithuanian sources. In witchcraft cases in Lithuania, searching for marks of the Devil was taken up only in the second half of the 17th century, when accusations of collaborating with the Devil increased. It was believed that the Devil would mark each witch with a touch of his finger. Sometimes bruises resulting from torture would be considered marks of the Devil: 'the tortured person had clear Devil's markings on his body, on his arms from his shoulders and on his legs from his knees, all bloody and bruised.' ${ }^{153}$ In 1731, Barbora Šimkaityte from the village of Šerkšnėnai admitted during interrogation to having an impression on her back, which had been made with a hot iron. ${ }^{154}$ Her brother Kazimieras claimed to have a Devil's nail mark on his chest. ${ }^{155}$ In 1725, when the Batakiai estate maid Kristina was inspected, two marks were found on her body, a red mark on her left side, and a black one on her stomach. ${ }^{156}$ In 1746, Jonas Steižys from the village of Čiovydžiai admitted he had one mark under his tongue, and that he was meant to receive a second one before the feast of St John (Midsummer). ${ }^{157}$ It was alleged that the extent of a witch's power was relative to the number of Devil's marks on the body. Someone with only one mark could only cast spells on animals. They could cast a spell, but they were not considered powerful enough to retract it. Having received a second mark, they would be able to cast spells on people as well, and retract spells too. ${ }^{158}$ The same categorisation of witches was mentioned in Malleus Maleficarum. ${ }^{159}$

A Devil's mark could be visible or invisible. It was special in that the area of skin was not sensitive, and blood would not flow from it. Thus, another form of ordeal for witches was needle pricking, to search for non-sensitive, bloodless places on the body. There is no data about this test in Lithuania. Weight and fire ordeals were not used in Lithuania either.

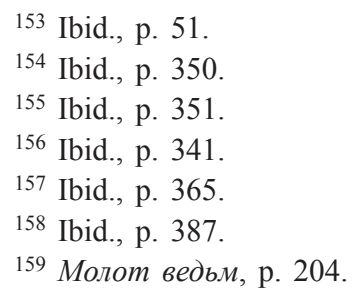


What is interesting is that Malleus Maleficarum was very sceptical about such ordeals. Many are not mentioned at all in the book, while the fire ordeal was condemned outright, as fire was held to be the Devil's element. ${ }^{160}$ According to the authors of Malleus Maleficarum, the only reliable means of testing for witches was the tear ordeal. ${ }^{161}$ It was believed that a witch under the control of the Devil would not be able to cry. During an inquiry, the judge was recommended to make the accused cry in the name of Jesus, the Blessed Virgin Mary and all the saints. If the woman did not cry, that meant she was a witch. If the woman did not even cry during torture, it was considered as direct evidence that she had indeed used spells. Instructio of 1657 dismissed all such evidence as completely unreliable. ${ }^{162}$ There are no direct mentions of the tear ordeal in Lithuania. However, as is mentioned earlier, insensitivity to pain was considered the outcome of spells, even in the Statute of Lithuania.

\section{II.4. Imprisonment}

If the accusation appeared to have solid grounds in court, the accused would be imprisoned. A search would be made of their home to find the implements and means for casting spells, whereupon they would be confiscated. In Lithuania, the accused would be asked to show where they hid their spell making equipment, which was sometimes invisible to the eye of a normal human. ${ }^{163}$

After making a confession, or sometimes without making a confession during the inquiry or ordeals, the person would be imprisoned. If the procedure was held in a castle or Magdeburgian court, the accused would be imprisoned in the court's prison. In rural areas and on estates, the accused would be imprisoned in the home of an estate official, or even in the plaintiff's home. ${ }^{164}$ In Polish historiography, there is an interesting account of the imprisonment of witches in barrels. Accused witches were placed in barrels, with their hands and feet tied behind their back. The knot would be drawn through a hole in the bottom of the barrel. That meant the

160 Ibid., p. 380.

161 Ibid., p. 369.

162 Instructio circa judicia sagarum, pages unnumbered.

163 Raganu teismai Lietuvoje, p. 28.

164 Ibid., pp. 79, 241, 302. 
accused had to stay constantly in a kneeling position, unable to either stand up or sit down. The barrel was covered with a thick fabric, and 'Jesus, Mary, Joseph' would be written on the side, in order to protect the woman inside from the Devil's influence. ${ }^{165} \mathrm{~A}$ chest or blocks could be used instead of a barrel, but the accused would be locked in such a way that her feet would not touch the ground. It was thought that witches could draw on magic power from the ground, strengthening their spells and possibly getting loose. ${ }^{166}$ The Samogitian bishop A. Tiškevičius described a similar method of imprisonment in Lithuania: 'They are stuck inside the same barrel, with the eyes covered and the hands bound behind their back.' 167 It should be noted that Malleus Maleficarum mentioned a similar way of raising a witch from the ground by her hands, shoulders or in a basket during her arrest or imprisonment. This was viewed rather cautiously, but it was deemed effective: it was said to make them less persistent and less likely to break free. ${ }^{168}$ However, in witchcraft trials in Lithuania, witches were usually tied up and imprisoned under a wooden tub. For example, in 1731, the family of Kazimieras Šimkus in the village of Šerkšnenai, who had all been suspected of witchcraft, were imprisoned in the home of the bencher D. Miltinis and stuck under tubs. ${ }^{169}$ In 1746, in the village of Čiovydžiai, a witch was also imprisoned under a tub. ${ }^{170}$ This form of imprisonment did not offer protection from the Devil. In 1725, when the Batakiai estate maid Kristina was being held prisoner, it was stated that when she was 'stuck under the tub, the evil spirit would enter through the stove and the bottom of the tub, untie her ropes and threaten to strangle her'. ${ }^{171}$ In 1746, Jonas Steižys explained how the Devil would appear before him for as long as his mother was held captive under a tub. The Devil would even bring her food. ${ }^{172}$ Sometimes the accused were held captive in blocks. ${ }^{173}$

$165 \mathrm{~K}$. Koranyi, Ze studiów nad wierzeniami w historii prawa karnego. Beczka czarownic (Lwów 1928), p. 7.

166 Ibid., pp. 7-8.

167 J. Lebedys, Lietuviu kalba, p. 202

168 Молот ведьм, р. 352.

169 Raganu teismai, p. 349.

${ }^{170}$ Ibid., p. 366.

171 Ibid., p. 338.

172 Ibid., p. 366.

173 Ibid., p. 240. 
Thus, these means of imprisonment did not really serve all their functions: they did restrict freedom and movement, but they did not interfere with further communication with the Devil.

\section{II.5. Torture}

The main form of evidence during the court procedure was considered a confession. So when there was obvious evidence, or the plaintiff had sworn that the accused was a witch, but the accused denied it, torture would be allowed. There were even cases when torture was applied even after a confession, in order to find out about any collaborators. ${ }^{174}$ Note that the authors of Malleus Maleficarum did not think that torture would always be successful. That would depend on God's will. So judges were warned against employing torture too much and rushing to include it in the procedure. At first, it was recommended that the accused be coaxed into confessing, with the help of respected people. ${ }^{175}$ Attempts would be made to break the woman's spirit by making the conditions of imprisonment increasingly worse. Even trickery was allowed: those who confessed were promised a lesser punishment. Torture was only meant to be used in extreme cases. ${ }^{176}$ The severity of the torture had to correspond with the severity of the crime, and to grow more brutal in increments the longer the accused did not confess. According to Malleus Maleficarum, torture could only be prolonged, but not repeated, unless new evidence emerged. ${ }^{177}$ However, in practice, courts would revert to torture quite quickly, and it would be enacted with great diligence. Secular legal acts regulated torture in witchcraft cases in Lithuania. Chapter 13 Article 14 of the First Statute of Lithuania stated that the accused could be tortured three times a day. However, if a confession was not elicited, the person who submitted the person to torture had to compensate the accused: to pay half a rouble for each case of torture, i.e. around 50 groschen. If the accused happened to die under torture without confessing, the torturer would have to pay so-called head-money, the amount of which depended on the social status of the person. Magdeburg Law also stipulated that torture could only go ahead when there

\footnotetext{
174 Ibid., p. 180.

175 Молот ведьм, р. 366.

176 Ibid., p. 388.

177 Ibid., p. 368.
} 
was a firm conviction that the accused was indeed guilty. ${ }^{178}$ If the suspicions were serious, the Carolina legal code also allowed torture. However, the oath of two witnesses was required in the presence of the accused. If a judge allowed torture without firm evidence, he would have to compensate the accused for the pain they experienced. ${ }^{179}$ The severity of the torture was also defined in legal acts: arms or legs could not be broken, internal organs could not be crushed. But in reality, these boundaries were often crossed. It was precisely in this part of the court procedure in Western Europe that the characteristics of crimina exepta become very evident. In an ordinary court procedure, torture was allowed only when the guilt of the accused was already completely proven. Torture could only be applied once, and for no longer than an hour. And if the accused still failed to confess, they had to be set free. In witchcraft trials, they would be tortured until they confessed. Usually, even having survived torture, the accused would still be punished with death. Instructio of 1657 tried to regulate the duration of torture, limiting it to under an hour, and prohibiting its repetition. ${ }^{180}$

In witchcraft trials in Lithuania, torture became more frequent from the 1630s, when judges were more persistent in trying to elicit a confession. Before then, a case would often close with oaths being made. The court would allow torture at the plaintiff's request, and taking the circumstances into consideration. In estate courts, torture was not restricted. It would be left to the master's will. The most frequently applied forms of torture were stretching, and torture by fire. ${ }^{181}$ Sometimes, a public lashing would be a form of torture. ${ }^{182}$ The already-mentioned bishop A. Tiškevičius wrote: 'They are given over to the executioner, who would torture them for three days, three times each day, using fire, and not letting them recover after each session of torture.' ${ }^{183}$ The torture was usually conducted in public. On the morning of 11 May 1655, Gertrūda Zaputkaitienè was tortured in the Raseiniai marketplace in the presence of many people and four vozny. She was tortured with various instruments, and

\footnotetext{
178 B. Groicki, Artykuły prawa magdeburskiego, p. 105.

179 Каролина, p. 44, статья 20.

${ }^{180}$ Instructio circa judisium sagarum, pages unnumbered.

${ }^{181}$ Raganu teismai Lietuvoje, pp. 47, 50.

182 Ibid., p. 366.

183 J. Lebedys, Lietuviu kalba, p. 202.
} 
stretched three times. ${ }^{184}$ In 1680 , at the Raulai estate in Samogitia, Zuzana Šleikienè was led out into the square. After a second round of interrogation, the accused was tortured three times. ${ }^{185}$ In 1697 , Mykolas Karalius was tortured three times with fire on the Kelme estate. A large crowd gathered to watch the torture. ${ }^{186}$ In 1646, in Merkine, Ona who was accused of witchcraft was tortured four times. ${ }^{187}$ The verdict of the Pinsk powiat cooperative court of 25 June 1684 was very telling: 'We have decided that according to the same [Statute] Chapter 14 Article 16, the said witch shall be given over to the executioner for torture, which shall last one hour, but on the provision that she not be injured, and if she confesses, she will have to be burnt to death; and if she does not confess, then, as foreseen in the Statute, we will see that the protesting party pay her compensation. ${ }^{188}$

Cases in the GDL where nobles would be tortured by a court order were especially rare, even though the Statute's articles which outline the conditions for torture do not mention any restrictions on torturing a noble. Therefore, there were similar cases among the court witchcraft trials. For example, in August 1614, at the Upyte castle court, torture was demanded for the noblewoman Ščasna Rokicka, from the Borovski (Borowski) line of dukes. ${ }^{189}$ In 1631, when the noblewoman (szliachtianka ucztivaja) Raina Gromykienè was put on trial at the Novahrudak castle court, she was found guilty and ordered to be tortured and punished. ${ }^{190}$ The torture was ordered on the basis of the 1578 Polish draft law of Jakub Psziluski, 'krom zadnego względu na zacnosc maia byc męczeni' (must be tortured, regardless of origins), the Emperor Justinian's legal code, 'abowiem zadna zasnosc czaradzieynika od męki wymowic nie moze' (no noble origins can save a witch from torture), ${ }^{191}$ Magdeburg Law, ${ }^{192}$ and

${ }^{184}$ Raganu teismai Lietuvoje, p. 243.

185 Ibid., p. 302.

186 Ibid., p. 312.

187 Ibid., p. 215.

${ }^{188}$ Lietuvos Didžiosios Kunigaikštystès kasdienis gyvenimas, eds. A. Baliulis, E. Meilus (Vilnius, 2001), p. 396.

189 Raganu teismai Lietuvoje, p. 93.

${ }^{190}$ Ibid., p. 41.

191 Ibid., p. 116.

192 Археографический сборник документов, t. 3, p. 127. 
the Old Testament. ${ }^{193}$ It could be that the court would sometimes pass a decision to torture a noble defendant under pressure from plaintiffs who held considerably higher positions in society. For example, Gromykienè was accused of attempting to cast a spell on the Lithuanian grand marshal Jonas Stanislovas Sapiega, and the palatine in Novahrudak where the court trial was held was his relative, Mikalojus Sapiega.

Some survived their torture. Explanations for survival rested on the actual use of spells or the Devil's help. In the late 17th century, it became common in witchcraft trials to think that, aside from using spells, the Devil could keep the accused alive or threaten her against confessing. For example, in 1691, the Devil was said to have kept alive Liucija Vaičiulyte, who was put on trial in the Šiauliai Economy, and she 'being completely possessed by an evil spirit, confessed little during the torture'. ${ }^{194}$ There are more cases where the Devil was said to have attempted to kill the accused, or encouraged her to kill herself. ${ }^{195}$ In 1725, in Batakiai, Kristina, the accused, barely recovered from her interrogation, as allegedly the Devil was trying to strangle her. ${ }^{196}$ In 1731, in the village of Šerkšnennai, Kazimieras Šimkaitis admitted that the Devil had come to him twice and reproached him for disclosing who were witches. ${ }^{197}$ In 1746, in the village of Čiovydžiai, Jonas Steižys explained that his mother would not admit to anything, as the Devil had appeared and threatened to twist off her head. ${ }^{198}$

During torture, the aim was to reach such a point that the accused would not care what they admitted to, as long as the torture would end. Questions were asked in such a way as to give the desired response. At the courts of the Inquisition, confessions during torture were viewed as the Devil retreating. In Lithuanian witchcraft court files, similar responses were noted from the late 17th century. The already-mentioned J. Steižys explained during his interrogation that the Devil had left him when he was being whipped by an apple tree. ${ }^{199}$

\footnotetext{
193 Ibid.

${ }^{194}$ Raganu teismai Lietuvoje, p. 51.

195 Ibid., pp. 365, 368.

196 Ibid., p. 338.

197 Ibid., p. 351.

198 Ibid., p. 366.

199 Ibid.
} 
A confession extracted during torture had to be repeated afterwards as well, so that the confession would be held as 'free and willing'. This is why in case files it was especially noted that the accused had confessed freely and willingly, and betrayed their collaborators. ${ }^{200}$ On occasion, the accused would retract the confession after torture, as they claimed to have mentioned innocent people purely due to the immense pain they were experiencing at the time. ${ }^{201}$ When the accusation was withdrawn, that person would no longer be persecuted.

\section{II.6. Appeals}

Malleus Maleficarum only foresaw the possibility of appeal in special cases. However, it had to be submitted to the same judge who presided over the initial court file, who would decide whether the appeal should go further, i.e. to the Curia in Rome. ${ }^{202}$ It was sometimes claimed in Lithuanian sources that an appeal in witchcraft trials was not allowed, unless the plaintiff or the court agreed. ${ }^{203}$ In the Statute of Lithuania, no such exception for those accused of witchcraft was mentioned. According to the Statute, anyone who risked the death sentence for a crime had the right to appeal. ${ }^{204}$ An appeal from the castle court would be presented to the Supreme Tribunal of Lithuania. The Statute also foresaw that the accused could be released until their case file reached its deliberation at the Tribunal, as long as that person had at least two bondsmen who could vouch for them, with their property and honour as a guarantee. If no such guarantors could be found, the accused had to wait for the Tribunal court in prison. ${ }^{205}$ If the master of a peasant put on trial at a cooperative court was not satisfied with the verdict, an appeal could be made to the land or castle court. ${ }^{206}$ Appeals from state estate regent's courts would be made to the court of the Economy regent, and from there the appeal would proceed to the Economy administrator's court. ${ }^{207}$ The highest appeal court in such cases was

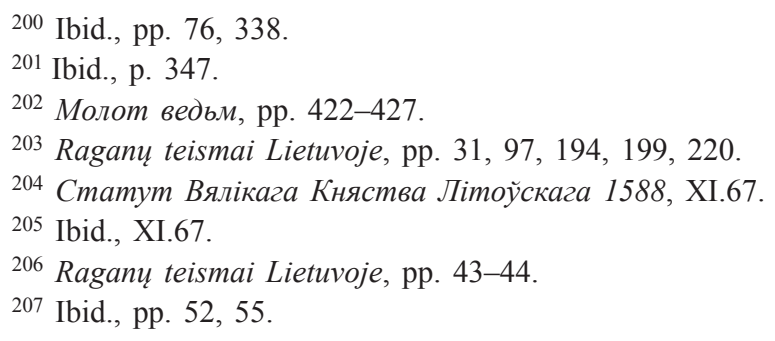


the royal referenderies' court. Appeals from the Magdeburgian court went to the assessor's court. An appeal was not allowed in private estate courts. The conclusion to many of these appeals is unknown. In some cases, the file would be returned to a lower court for another hearing, and the verdict would have to be implemented. ${ }^{208}$ It was not just the convicted who would lodge appeals, but plaintiffs as well, who might have been unhappy with the court's verdict when the accused was acquitted. ${ }^{209}$

\section{II.7. Punishment}

Only a confession and punishment could reconcile a witch with the Church. Formally, according to Malleus Maleficarum, the punishment had to be differentiated based on the severity of the crime. As was already mentioned, it was enough for an accusation to be made for someone to receive a punishment. Suspicions would be grouped as weak, strong or strongest. ${ }^{210}$ If the suspicion was weak or strong, but there was no evidence, the witch could avoid the death sentence by agreeing to a canon's cleansing or a public renunciation of heresy. ${ }^{211}$ In such cases, she had to receive a lesser punishment, for example, to stand in church during each Mass for a period of time, holding a piece of wax of a certain weight, or to agree to go on a pilgrimage to a holy site. ${ }^{212}$ If the suspicion was of the strongest level, the death sentence could be expected. However, even in these cases, by the judge's decision, if the accused renounced heresy and expressed remorse for their actions, they could avoid death and receive a life sentence instead. ${ }^{213} \mathrm{~A}$ witch who had confessed and expressed remorse, and if these were the first suspicions raised against her, could also theoretically receive just a life sentence in prison. ${ }^{214}$ The death sentence was reserved for those who had committed multiple acts of heresy, or those who had confessed but without remorse, ${ }^{215}$ as well as people who had

208 Ibid., pp. 38, 41.

209 Ibid., p. 183.

${ }^{210}$ To read about the classification and features of accusations, see: Молот ведьм, рp. 382-383.

211 Ibid., p. 386.

212 Ibid., pp. 393, 397.

213 Ibid., p. 394.

${ }^{214}$ Ibid., p. 398.

215 Ibid., pp. 400, 401. 
not confessed but whose guilt was proven in court. ${ }^{216}$ However, in reality, after torture, many accused simply confessed 'freely and willingly', and would receive the strictest punishment.

The death sentence. Burning was the most common punishment in Continental Europe. Secular members of society would pass the final verdict and see to its implementation. Malleus Maleficarum recommended that inquisitors who were also clergymen distance themselves from the death sentence by a formal court request to avoid 'the spilling of blood or the punishment of death' ${ }^{217}$ Burning was considered the salvation of the soul. The soul was expected to be cleansed in the flames. The suffering experienced during burning was like a form of remorse that was meant to shorten the suffering after death.

As a specific punishment for witchcraft was not mentioned in the Statute of Lithuania, the courts would usually rely on Christian law, the imperial code, ${ }^{218}$ Magdeburg Law, ${ }^{219}$, and examples of witch-hunts. All of these legal acts outlined the strictest punishment as burning. For example, the Carolina code of Emperor Charles $\mathrm{V}$ foresaw that if a witch had harmed people with her spells, she would be punished with death by burning. ${ }^{220}$ If no harm was done, another, less strict, punishment could be applied. In Europe, during the implementation of such punishments, a so-called gesture of mercy was quite popular, where the convicted would be strangled or beheaded before burning. There is no information about this in Lithuania. Even in cases where the convicted committed suicide while awaiting punishment, the body would still be burnt. ${ }^{221}$ Women who were expecting would temporarily avoid punishment. ${ }^{222}$ If during interrogation it became evident that the accused had used the Host for her spells, an even harsher punishment in Western Europe would be applied: first her hands would be burned slowly. This has not been noticed in Lithuania, although cases of profanity involving the Host did occur in some files. ${ }^{223}$

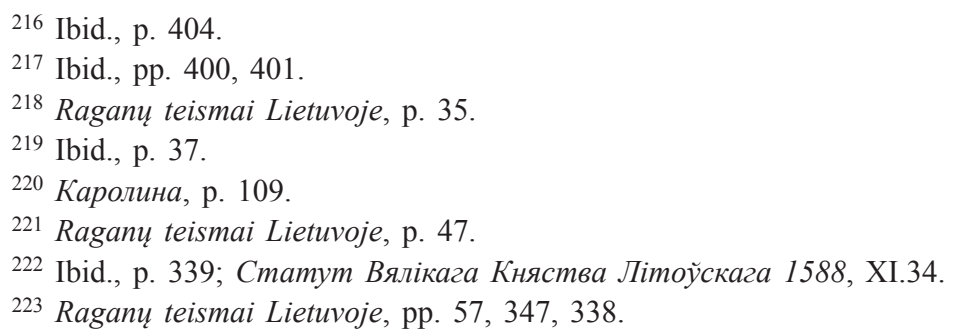


In Western Europe, the punishment was usually carried out by a professional executioner. In Lithuania, however, there are suggestions that the victim themselves could carry out the death penalty for a witch. For example, on 1 June 1581, the Kaunas voigt court decided that the plaintiff could carry out its verdict on the 'poisoner' Darata, accused of making several people fall ill: the plaintiff would have to kill her. ${ }^{224}$ The vozny and five invited nobles carried out the death penalty on Raina Gromykienè on 7 December 1631. ${ }^{225}$ In 1621, in the village of Kurkovičiai (in the Minsk palatinate), the collective designated the chamberlain to carry out their verdict. ${ }^{226}$ However, usually an executioner was appointed for the task. If a court did not have its own executioner, one would be invited from elsewhere. For example, in 1726, an executioner was invited from Hrodna to the Alytus Economy. ${ }^{227}$ If the appointed person could not be summoned to carry out the verdict, it could be implemented by anyone who had met him. ${ }^{228}$ The cooperative court members themselves could also carry out the punishment if needed. ${ }^{229}$

Some entries suggest that there were permanent witch-burning places. This is indicated in expressions in the case files such as 'in the regular spot', or 'where all witches are burnt'. 230 These places were usually on the outskirts of a village. ${ }^{231}$ In cities, a place would be set up beyond the city limits. ${ }^{232}$ For example, in Samogitia, one was set up outside Raseiniai near the gallows. ${ }^{233}$ Sometimes the punishment would be carried out in the city itself, on a special platform. In 1758, the death penalty was carried out in Vilnius on a group of people suspected of witchcraft, where a so-called theatre, or platform, was built. ${ }^{234}$ Of the published witch files, it becomes clear that a majority $(80 \%)$ of death sentences by

224 Ibid., p. 78.

225 Ibid., p. 42.

226 Ibid., p. 29.

227 Ibid., p. 347.

228 Ibid., p. 30.

229 Ibid., p. 345.

${ }^{230}$ Ibid., p. 64.

231 J. Putek, Mroki średniowiecza, s. 197; Археографический сборник, t. 1, no. 31 , p. 101.

${ }^{232}$ Raganu teismai Lietuvoje, p. 42.

${ }^{233}$ Ibid., p. 244.

234 J. Obst, Kat miasta Wilna, p. 173. 
burning were carried out in estate courts. The punishment ceremony was a public spectacle. The accusation would be read to the public at the place of burning, and the verdict would be carried out. Before the execution, the convicted could still retract their accusations against 'collaborators' they had betrayed. The death penalty did not always proceed smoothly. In the spring of 1680, in Samogitia, when Saliamonas Puzas was being burnt, observers were surprised that the bonfire would not burn, and that magpies were flying in circles above the victim. (Witches would turn into magpies and fly to their gatherings. $)^{235}$

Apart from burning, other forms of the death sentence were passed in Lithuanian witchcraft trials as well. In 1617, the Ukmerge castle court punished a woman from an estate family suspected of witchcraft and arson with death by hanging. ${ }^{236}$ This was the punishment foreseen in the Statute of Lithuania for arson. ${ }^{237}$ In 1641, in the Kupiškis starosty, several peasants were accused of witchcraft and of poisoning the children of Tyzenhauzas, the starosta of Kupiškis. One of the suspects, Mikalojus Vaivadonis, was beheaded. ${ }^{238}$ In 1694, on the Biržai estate, Barbora Nikielsova, who was accused of poisoning her husband (poisoning was often identified with witchcraft), was also beheaded. ${ }^{239}$

Adjudgement to the plaintiff. A lighter form of punishment was when the convicted was adjudged to the plaintiff. On 23 May 1602, the vozny's statement claimed that a year previously, the serf Gertrūda Jakutaite had cast a spell on the daughter of the Rietavas noble Valentinas Žvaginis. The noble sought justice in the Plunge estate court, which adjudged Gertrūda to Žvaginis. ${ }^{240}$ A similar case unfolded in 1641, when the brother of the victim vouched for a witch who was sentenced to death. In return, the convicted had to enter the service of her new master, the brother. ${ }^{241}$ In 1680 , in Žemaitija, five nobles vouched for a Lukavičienè, who had been

235 Raganu teismai Lietuvoje, p. 303.

236 Ibid., p. 154.

${ }^{237}$ Статут Вялікага Княства Літоусскага 1588, XI.18.

${ }^{238}$ Raganu teismai Lietuvoje, p. 207.

239 Biržu dvaro teismo knygos, eds. V. Raudeliūnas, R. Firkovičius (Vilnius, 1982), pp. 60-83.

${ }^{240}$ Raganu teismai Lietuvoje, p. 86.

241 Ibid., p. 206. 
accused of witchcraft, and four nobles vouched for M. Budreckas. In the end, the two accused were adjudged to those who had spoken in their favour. ${ }^{242}$ However, according to the Statute, nobles who were sentenced to death but who had bought their freedom, or had their friends plead on their behalf, still lost respect in the community, and lost their noble rights. ${ }^{243}$

Expulsion from the community. Sometimes the accusers did not demand the death sentence for the people they had convicted. For example, in 1695, residents of the village of Mitkunai reported that the Üba family exhibited asocial behaviour, threatened others, and engaged in witchcraft, and asked that they should be removed. The family was expelled from the village, with no permission to return, otherwise they would be punished with death. ${ }^{244}$ Sometimes, convicted people were banished to other estates. ${ }^{245}$ At the Paneriai estate in 1763, spell-casters and witches had to be flogged and expelled. ${ }^{246}$ In 1771, the Raseiniai Dominican monks decided to drive the Ruginis family, suspected of witchcraft, from their farm and lands, and in order to cover their expenses, the Dominicans took over half the family's property. ${ }^{247}$

Expulsion was sometimes combined with punishment of the body and one's honour. For example, in 1646 in Merkine, the suspect Ona was handed over to the executioner to be flogged at the stake, have a mark burnt into her skin, and to be driven from the town for all time. Anyone who dared to take her into their homes would also be severely punished. ${ }^{248}$ The burning of a mark on the body was typical of Magdeburg Law, but it was not mentioned in the Statute. People who had not come of age and were accused of witchcraft would often be sentenced to corporal punishment instead of death. ${ }^{249}$ According to the Statute of Lithuania, people under the age of 16 were not given the death sentence. ${ }^{250}$

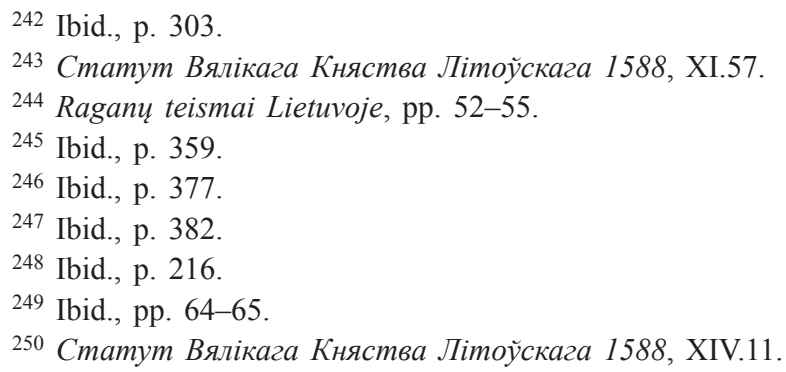


Corporal punishment would sometimes be combined with church punishment. ${ }^{251}$ In 1702, the Joniškis estate court ordered Girnienè, who was accused of witchcraft, to pay the plaintiff the sum he had lost for the horses she killed, and to perform a penance. For three weeks, on Thursdays, Fridays and Sundays, she had to kneel before the church altar in public, with a candle and clothed in a blanket, and flog herself at the elevation of the Host, and to live near the church shelter for as long as her penance lasted, suffering her punishment. ${ }^{252}$ In May 1709, the Kobryn magistrate court convicted the burgher Apolonija Kyšelova of using spells to attract a husband: her punishment was to lie in the Orthodox church during Mass, and then to endure 50 lashes in the town square. ${ }^{253}$

Sometimes, if there was a lack of evidence, the accused could be given a monetary punishment. For example, on 3 July 1731 in Kražiai, because of the lack of evidence, some of the accused were set free. However, they were ordered to pay 50 kapa of groschen if they did not show remorse and tried to harm the plaintiffs. ${ }^{254}$ Monetary punishment started to be applied for erroneous accusations of witchcraft in the 18th century. The Žagare estate court was especially known for this in the mid-18th century. The surviving estate court books suggest that there were conscious efforts not to allow witchcraft trials to take place at all. As soon as a complaint was received, the court tried to reconcile both parties. ${ }^{255}$ Failing that, the accused was allowed to clear their name by taking an oath, while the plaintiff would be punished for defamation or injury. ${ }^{256}$ This was probably due to the personal view of witchcraft trials of the person who acted as the estate regent at that time.

In rarer cases the punishment of imprisonment would be given. This kind of sentence was handed down in the Žagare estate court, where on 25 June 1742, an accused woman was sentenced to 12 weeks in prison, and had to present a guarantor who could vouch that she would never harm anyone again. ${ }^{257}$ Two months later,

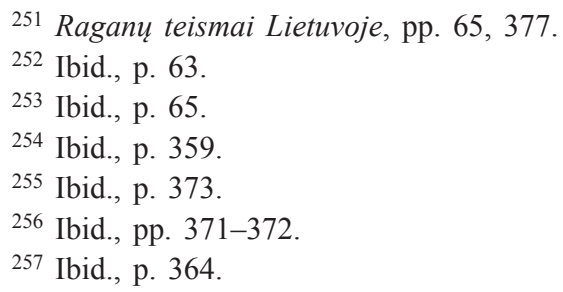


another witchcraft case was brought before the court. The accused was again sentenced to prison and had to present guarantors. ${ }^{258}$

Discharge from punishment. On occasion, the plaintiff would discharge the defendant from punishment. Sometimes the accused would swear not to cast spells again, and to retract the spells already made. ${ }^{259}$ Several women were tried in 1639 in Samogitia who were accused of making the landowner Sofija Preikintaite Sugintiene Janavičiene fall ill. One of the accused confessed, and promised to make the woman well again. For this deed, she received a written pardon. ${ }^{260}$ Pardons were also granted to those who accepted the blame on behalf of someone else. In 1655 in Samogitia, the tailor Matijošius Urbonaitis Talačkaitis and his daughter Sofija were accused of casting a spell on the wife of the Lubiai estate owner J. Šostovickas. Both admitted to engaging in witchcraft; however, only the father was burnt, as he took the blame for his daughter as well. ${ }^{261}$

\section{Conclusions}

1. There is more thorough documentation of witchcraft court procedures from the mid-16th century, when they finally came under the jurisdiction of the secular courts. The social class of the plaintiff and defendant determined which court would preside over their case. Burghers from Magdeburgian cities were tried in the voigt and benchers' or magistrate courts in accordance with Saxon law. Nobles were put on trial in the castle court, as outlined in the Statute of Lithuania, while peasants were judged in the cooperative, estate owner or manager's court. The clergy's efforts to bring witchcraft trials back into the canonical courts were unsuccessful. As witchcraft trial procedure was not clearly regulated in the Statute of Lithuania, cases were deliberated in the context of Magdeburg, Christian and Polish law, and referred to examples of witch-hunts from other countries. The book Malleus Maleficarum was not mentioned directly in case files, but the provisions it outlined appear.

258 Ibid., p. 364.

259 Ibid., p. 330.

${ }^{260}$ Ibid., p. 204. However, when the plaintiff grew even more ill, she cancelled her notice and obliged her sons to have the witches convicted after her death.

${ }^{261}$ Ibid., p. 240. 
2. Differences between the witchcraft trial procedure in Lithuania and that described in Malleus Maleficarum emerge in the presentation of accusations. Whereas Malleus Maleficarum recommended the anonymous presentation of the accusation, where the accuser and witnesses would remain unidentifiable, in Lithuania the regulations foresaw a personal expression of the accusation, where the accused would always know who had made the accusation against them.

3. In Lithuanian witchcraft trials, witches would be accused of causing harm to life, health or property through the use of spells. They were not accused of heresy in secular courts, even if it became evident during the court procedure that there had been instances of collaboration with the Devil. This kind of collaboration was more prevalent only from the mid-17th century, and made up barely $10 \%$ of all known cases.

4. Another difference was that in Lithuania, the accused could have someone serve in their defence who was free to act as they saw fit. However, this depended on who was being put on trial, and in which court the case was being deliberated. If the trial took place in the Magdeburgian or castle courts, the presence of a defender was foreseen in legal acts, while in estate courts, all variables were left to the will of the estate's owner.

5 . The further court procedure did not differ much between courts serving different social estates. Of the numerous witchcraft ordeals known in Western Europe, two were usually used in Lithuanian courts, floating and searching for marks of the Devil. One of the most popular forms of torture was stretching and burning (with a candle or straw). Both Malleus Maleficarum and secular legal acts determined the duration of the torture and restrictions on its severity, although in reality, these limitations were not always followed.

6. Accused who were Magdeburgian city dwellers, nobles or state peasants had the right to appeal in a Magdeburgian or castle court (private peasants did not have this right). However, in actual fact, state peasants could not always make use of this right.

7. A fifth of all the accused in Lithuania were sentenced to the most severe form of punishment, death, and mostly in estate courts. The life sentence mentioned in Malleus Maleficarum was never applied in Lithuania. Lighter forms of punishment were also given, especially if the convicted never caused someone's death: these could be expulsion from the community, the adjudgement of the convicted person to a guarantor, or flogging. Church punishments were also handed down. 
The image of a demonised witch as the Devil's helper, a heretic who had rejected the true faith, never really formed in Lithuania. That is why witchcraft court procedures were more similar to regular criminal court cases than the witchcraft trial procedures that were widespread in Western Europe.

Author Details

Gitana Zujiene is a researcher in the Department of the Grand Duchy of Lithuania at the Lithuanian Institute of History. Her main research interests are auxiliary historical sciences (legal archaeology) and legal history.

Address: Lithuanian Institute of History, Kražių g. 5, LT-01108, Vilnius

E-mail: gzujiene@gmail.com

\section{References}

ADAMCZYK, J. 'Procesy o czary w Polsce w wiekach XV-XVIII, Małgorzata Pilaszek', Kraków, 2008 (recenzja)', in Przegląd Historyczny, 100/4 (2009), pp. 839-843.

ADAMCZYK, J. 'Czary i magia w practyce sądów kościelnych na ziemiach polskich wpóżnym średniowieczu (XV-połowa XVI wieku)', in Karolińscy pokutnicy i polskie średniowieczne czarownice, wyd. M. Koczerska (Warszawa: Wydawnictwo DiG, 2007), pp. 91-260.

ALIŠAUSKAS, V. 'Jono Lasickio pasakojimas apie žemaičių dievus: tekstas ir kontekstai', in Baltų mitologijos ir ritualo tyrimai, 6 (Vilnius: Aidai, 2012).

AUGSKALNIS, A. 'Tilžès lietuvių burtai XVI a. teismo aktuose', in Tautosakos darbai, 3 (Kaunas: Lietuvių tautosakos archyvas, 1937), pp. 239-243.

BASCHWITZ, K. Czarownice. Dzieje procesów o czary (Warszawa: Cyklady, 1999).

BERESNEVIČIUS, G. ČAPLINSKAS, Tomas, 'Ragana', in Lietuvos Didžiosios Kunigaikštijos kultūra. Tyrinejimai ir vaizdai, sud. V. Ališauskas, L. Jovaiša, M. Paknys, R. Petrauskas, E. Raila (Vilnius: Aidai, 2001), pp. $557-573$.

DUNDULIENĖ, P. 'Siaubinga praeitis', in Mokslas ir gyvenimas, 6 (1958), pp. 31-36.

DUNDULIENĖ, P. 'Kelias ị laužą', in Mokslas ir gyvenimas, 4 (1959), pp. 28-31.

DYSA, K. Witchcraft Trials and Beyond: Trials for Witchcraft in the Volhynian, Podolian and Ruthenian Palatinates of the Polish-Lithuanian Commonwealth in the Seventeenth and Eighteenth Centuries (Budapest: Central European University Press, 2011). 
GAŁUSZKA, T. 'Magia jako factum haereticale. Wokól bulli Jana XXII Super illius specula', in Przeglad Historyczny, 2 (2006), pp. 221-240.

GIMBUTIENE, M. Senoves lietuviu dievai ir deivés (Vilnius: Lietuvos rašytojų sajungos leidykla, 2002).

GRAHAM-LEIGH, E. The Southern French Nobility and the Albigensian Crusade (Woodbridge: The Boydell Press, 2005).

GREIMAS, A.J. Lietuviu mitologijos studijos (Vilnius: Baltos lankos, 2005).

JODKOWSKI, J. O czarowniku Znaku na inkwizycji $w$ Grodnie $w$ 1691 r. (Lwów: Drukarnia L. Wiśniewskiego, 1932).

JUCEVIČIUS, L. Raštai (Vilnius: Valst. grožinès lit-ros 1-kla, 1959).

JURGINIS, J. 'Raganų teismai', in Raganu teismai Lietuvoje, ed.

K. Jablonskis, R. Jasas (Vilnius: Mintis, 1987), pp. 11-23.

JURGINIS, J. Raganu gaudymo šimtmetis (Vilnius: Mokslas, 1984).

KAVOLIS, V. Moterys ir vyrai lietuviu kultūroje (Vilnius: Lietuvos kultūros institutas, 1992).

KIELA, K. 'Raganų deginimas Lietuvoje', in Diena (1935 07 07); Lietuvos žinios (1935 08 25).

KNIEŽAITE், M. 'Raganas prisimenant ne iš pasakų', in Lietuvos žinios (2015 07 22)

KORANYI, K. 'Czary i gusła przed sądami kościelnymi w Polsce w XV i pierwszej połowie XVI wieku', in Lud, 26 (1927), pp. 1-25.

LOBAČ, U. 'Burtininkavimas krivičių žemèse', in Liaudies kultūra, 3 (1999), pp. 53-55.

NACHMAN, B-Y. 'The European Witch Craze of the 14th to 17th Centuries: A Sociologist's Perspective', in American Journal of Sociology, Vol. 86, No. 1 (July 1980), pp. 1-31.

OSTLING, M. Between the Devil and the Host: Imagining Witchcraft in the Early Modern Poland (Oxford University Press, 2011).

PILASZEK, M. 'Fiasko europejskiego polowania na czarownice XVIXVIII w.?', in Przeglad Historyczny, XCII, z. 4 (2001), pp. 461-475.

PILASZEK, M. 'Litewskie procesy czarownic', in Odrodzenie i Reformacja, 4 (2002), pp. 7-35.

PILASZEK, M. Procesy o czary w Polsce $w$ wiekach XV-XVIII (Kraków: Universitas, 2008).

POŠKA, D. Raštai (Vilnius: Valstybinè grožinès literatūros leidykla, 1959).

PUTEK, J. Mroki średniowiecza (Warszawa: Państwowy Instytut Wydawniczy, 1985).

RYAN, W.F. 'The Witchcraft Hysteria in Early Modern Europe: Was Russia an Exception?', in The Slavonic and East European Review, vol. 76, no. 1 (January 1998), pp. 49-84.

SABAITYTĖ, G. 'Raganų "medžioklès” atgarsiai XVI-XVII a. pirmos pusès Kaune', in Kauno istorijos metraštis, 8 (Kaunas: VDU leidykla, 2007), pp. 279-296. 
SABAITYTĖ, G. 'Raganų tapimas "užribio žmonėmis” Lietuvos Didžiojoje Kunigaikštystejje', in LIM, 2009/1 (Vilnius: Lietuvos istorijos instituto leidykla, 2010), pp. 69-88.

SABAITYTĖ, G. Užribio žmonès Lietuvos Didžiosios Kunigaikštystès visuomenèje, doctoral dissertation, VDU (Kaunas: VDU leidykla, 2010).

SEGL, P. 'Heinrich Institoris. Persönlichkeit und literarisches Werk', in Der Hexenhammer. Entstehung und Umfeld des Malleus maleficarum von 1487, ed. P. Segl (Böhlau Verlag Köln-Wien, 1988), pp. 103-126.

SOCHANIEWICZ, K. 'Przyczynek czarów na Źmudzi w XVII wieku', in Lud, Serja 2, t. 1 (Lwów: Polskie Towarzystwo Ludoznawcze, 1922), pp. 125-135.

ŠINKŪNAS, F. 'Lietuviški žavètojai ir raganos', in Mokykla ir gyvenimas, 6 (1930), pp. 293-301.

TUČAS, P. ‘Ragana ant laužo Ukmergèje', in Lietuvos aidas, 130 (1939 03 20).

VALANČIUS, M. Raštai, 2 (Vilnius: Vaga, 1972).

VÉLIUS, N. Mitinès lietuviu sakmiu bütybès: laimès, laumès, aitvarai, kaukai, raganos, burtininkai, vilktakiai (Vilnius: Vaga, 1977).

WIJACZKA, J. 'Procesy o czary w Polsce w epoce wczesnonowożytnej', in Kwartalnik Historyczny, R. XCVI, z. 3 (2009), pp. 113-127.

WRZESINSKI, S. Inkwizycja na ziemiach polskich (Zakrzewo: Replika, 2009).

ZGUTA, R. 'The Ordeal by Water (Swimming of Witches) in the East Slavic World', in Slavic Review, vol. 36, no. 2 (June 1977), pp. 220-230.

ZUJIENE, G. 'Theatrum poenarum Lietuvos raganų teismuose XVIXVIII a.', in Ministri historiae. Pagalbiniai istorijos mokslai Lietuvos Didžiosios Kunigaikštystès tyrimuose, ed. Z. Kiaupa, J. Sarcevičienè (Vilnius: Lietuvos istorijos instituto leidykla, 2013), pp. 343-362.

БЫЛЬ, В. Асаблівасці ведаўскіх працэсаў на землях Вялікага княства Літоўскага ў XVI-XVIII стст.', in Европа - 2010: глобальное $и$ локальное (Вильнюс: ЕГУ, 2011), pp. 84-92.

ДОВНАР ЗАПОЛЬСКИЙ, М. 'Чародейство в Северо-Западном крае в XVII-XVIII вв.', in Исследования и статьи, 1 (Киев: Изд. А. П. Сапунова, 1909), рр. 214-231.

ДИСА, К. Історія з відьмами. Суди про чари в українських воэводствах Речі Посполитої XVII-XVIII столиття (Київ: Критика, 2008).

ЛОБАЧ, У. 'Чараўніцтва на Беларусі на тле сярэднявечных судовых працэсаў’, in Kpыўя. Crivica. Baltica. Indogermanica, 1 (1998), pp. 87-99.

ЛОБАЧ, У. 'Да механізму чарадзейскіх працэсаў у сярэднявечнай Беларусі: на прыкладзе справы палачаніна В. Брыкуна (1643 г.)', in Беларускі горад у часе і прасторы: 500 гадой Полачкай магдэбургіi (Наваполацк: ПДУ, 2001), pp. 52-59.

ЛОБАЧ, У. 'Вядзьмарскі працэс 1691 г. у Гародні: да тыпалогіі чарадзейскіх спраў у сярэднявечнай Беларусі', in Культура Гродзенскага рэгіёну: праблемь развічия ва ўмовах поліэтнічнага сумежжа (Гродна: ГрдУ, 2003), рр. 20-25. 
ЛОБАЧ, У. 'Чараўнік', іп Беларуская міфралогія (Мінск: Беларусь, 2006), p. 549.

ЛОЗИНСКИЙ, С. 'Роковая книга', in Шпенгер, Я., Инститорис, Г. Молот ведьм (Санкт Петербург: Амфора, 2005).

Памятная книжка Ковенской губернии на 1900 год (Ковна: Типография Губернского Правления, 1899), рр. 146-156.

СПРОГИС И. Народньй суд литвинов над колдунами (Витебск: Губ. типо-лит, 1896). 


\title{
RAGANAVIMO BYLOS LIETUVOS DIDŽIOJOJE KUNIGAIKŠTYSTÉJE XVI-XVIII A.
}

\author{
Santrauka
}

\section{GITANA ZUJIENE}

Straipsnyje analizuojamas raganų teismo procesas Lietuvoje. Aiškinamasi, kokie teisès aktai reglamentavo jo eigą, kokie teismai sprendè tokio pobūdžio bylas. Raganų teismai Lietuvoje lyginami su teismu, aptartu 1487 m. Jakobo Šprengerio ir Henriko Institorio išleistoje knygoje „Raganų kūjis“, atskleidžiami procesų panašumai ir skirtumai.

Lietuvoje raganų teismai išsamiau dokumentuoti nuo XVI a. vidurio, kai jie galutinai atiteko pasaulietinių teismų kompetencijai. Kokiame teisme bus svarstoma byla, priklausė nuo įtariamojo ir ieškovo socialinio sluoksnio. Magdeburginio miesto miestiečiai buvo teisiami pagal vokiškają teisę magistrato teisme, bajorai - pilies teisme, valstiečiai - kuopos, dvaro savininko arba valdytojo teisme. Kadangi Lietuvos Statute raganų teismo procesas nebuvo aiškiai reglamentuotas, svarstant bylas buvo pasiremiama ir magdeburgine, krikščioniškaja, lenkiška teise, vadovautasi raganų gaudymo pavyzdžiais. Pats „Raganų kūjis“ bylose tiesiogiai neminimas. Skirtumai tarp raganų teismo proceso Lietuvoje ir „Raganų kūjyje“ ryškejja jau kaltinimo pateikime. „Kūjyje“ rekomenduotas anoniminis įtarimo pareiškimas, kai kaltintojas ir liudininkai ịtariamajam lieka nežinomi, o Lietuvoje reglamentuotas asmeninis kaltinimo pareiškimas, kai įtariamasis visada aiškiai žinodavo, kas ir kuo jị kaltina. Raganos Lietuvos Teismuose kaltinamos pasinaudojusios burtais ir taip pakenkusios gyvybei, sveikatai arba turtui. Kaltinimas erezija joms neformuluojamas net bylos eigoje paaiškejjus „bendravimo su velniu“ faktui. Pastarieji dažnesni tik nuo XVII a. vidurio ir sudaro vos apie 10 proc. visų bylų. Kitas skirtumas - galimybė ịtariamajam turèti gynejją ir gynejjo veikimo laisvè. Ji priklausè nuo to, kas buvo teisiamasis ir kokiame teisme byla buvo svarstoma. Magdeburginiame ir pilies teismuose gynejjo buvimą reglamentavo teisès aktai, o dvaro teisme viskas buvo palikta dvaro savininko valiai. Tolesnis teismo procesas skirtingų luomų teismuose labai nesiskyrè. Iš daugybės raganų bandymų, žinotų Vakarų Europoje, Lietuvos teismuose naudoti du - plukdymas ir velnio žymių paieška. Populiariausi kankinimo būdai - tempimas ir deginimas ugnimi (žvake, šiaudais). Tiek „Raganų kūjis“, tiek pasaulietiniai teisès aktai numatẻ kankinimų trukmès, stiprumo ribojimus, tačiau realybeje to ne visada buvo laikomasi. Apeliacijos teise realiai pasinaudoti galejjo tik aukštesnių socialinių sluoksnių įtariamieji, teisiami magdeburginiame ir pilies teismuose. Aukščiausia, mirties, bausme (sudeginimu) Lietuvoje buvo nubausta penktadalis visų įtariamųų. Vienu atveju įtariamoji buvo pakarta, dviem atvejais - nukirsdinta. „Raganų kūjyje“ minimas galimas ịkalinimas iki gyvos galvos Lietuvoje nepraktikuotas. Taikytos ir lengvesnès bausmės, ypač jeigu kaltinamojo veiksmai nesukèlẻ kito žmogaus mirties - išvarymas iš bendruomenès, kaltinamojo priteisimas laiduotojui, išplakimas. Taip pat taikytos bažnytinès bausmės.

Demonizuotos raganos kaip velnio pagalbininkès, tikrojo tikejjimo atsisakiusios eretikès ịvaizdis Lietuvoje iki galo taip ir nesusiformavo. Dẻl šios priežasties jų teismo procesas artimesnis paprastų baudžiamujų bylų procesams, nei Vakarų Europoje paplitusiems raganų teismams. 